Tjalling C. Koopmans Research Institute Tplligh Aoopman

Discussion Paper Series nr: 13-06

\title{
Is there an optimal pension fund size? A scale-economy analysis of administrative and investment costs
}

Jacob A. Bikker 


\section{Tjalling C. Koopmans Research Institute Utrecht School of Economics Utrecht University}

Kriekenpitplein 21-22

3584 EC Utrecht

The Netherlands

telephone $\quad+31302539800$

fax +31302537373

website www.koopmansinstitute.uu.nl

The Tjalling C. Koopmans Institute is the research institute and research school of Utrecht School of Economics.

It was founded in 2003, and named after Professor Tjalling C. Koopmans, Dutch-born Nobel Prize laureate in economics of 1975.

In the discussion papers series the Koopmans Institute publishes results of ongoing research for early dissemination of research results, and to enhance discussion with colleagues.

Please send any comments and suggestions on the Koopmans institute, or this series to J.M.vanDort@uu.nl

ontwerp voorblad: WRIK Utrecht

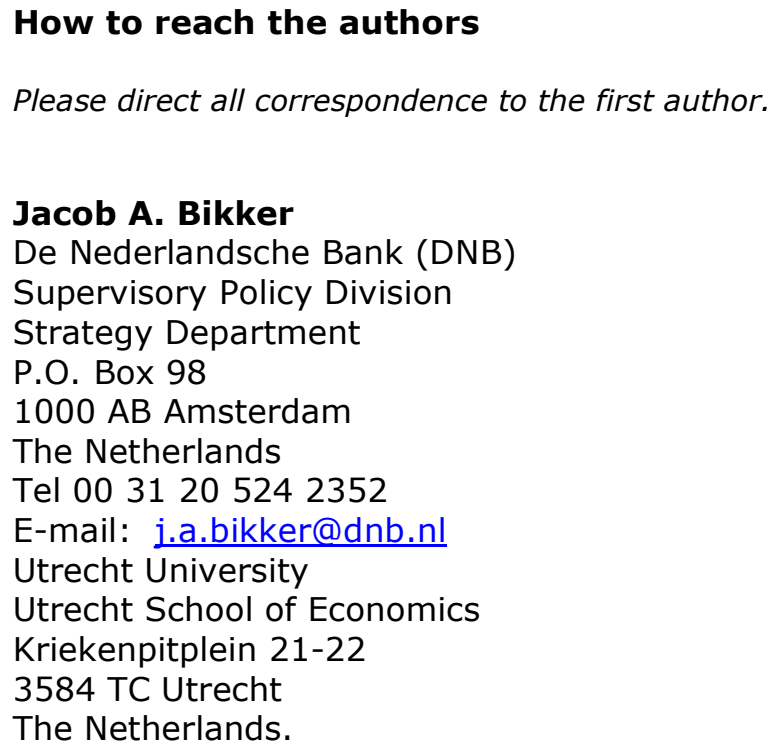


Utrecht School of Economics

Tjalling C. Koopmans Research Institute

Discussion Paper Series 13-06

\title{
Is there an optimal pension fund size? A scale-economy analysis of administrative and investment costs
}

\author{
Jacob A. Bikker \\ Utrecht School of Economics \\ Utrecht University
}

April 2013

\begin{abstract}
This paper investigates scale economies and the optimal scale of pension funds, estimating different cost functions with varying assumptions about the shape of the underlying average cost function: Ushaped versus monotonically declining. Using unique data for Dutch pension funds over 1992-2009, we find that unused scale economies for both administrative and investment activities are indeed large and concave, that is, huge for small pension funds and decreasing with pension fund size. For administrative activities, we observe a clear optimal scale of around 40 thousand participants during 1992-2000 (pointing to a U shaped average cost function), which increases sharply in subsequent years to size above the largest pension fund, pointing to monotonically decreasing average costs. As regards investment costs we observe an optimal scale for total assets of around $€ 690$ million and larger, without a clear shift over time and without diseconomies of scale for larger funds. The results are very sensitive to the correct functional form of the cost model. Consolidation among especially smaller and medium-sized pension funds would increase cost efficiency.
\end{abstract}

Keywords: Pension funds; unit-costs function, administrative costs, investment costs, economies of scale, pension plan design, governance, defined benefits, defined contribution, outsourcing, reinsurance.

JEL classification: G23.

Acknowledgements

The author is grateful to Dirk Broeders and Paul Cavelaars for useful comment, Ingeborg Bikker for mathematical advice and Jack Bekooij for excellent research assistance. Views expressed are those of the author and do not necessarily reflect official positions of DNB. 


\section{Introduction}

Since the credit crisis, pension funds all over de world have suffered from low returns on stocks, low interest rates and, particularly funds that offer defined benefit plans, increasing life expectancy. The operating costs of pension funds may draw less attention, although persistent inefficiencies are seriously eroding (future) benefits. Ambachtsheer (2010) stresses the role of operating efficiency in optimal pension provision and indicates that more research is needed on institutional implementation. Comparing pension funds in the Netherlands, one finds that avoidable costs may cause a $10 \%-20 \%$ difference between benefits paid by the smallest and by the largest pension funds, a difference that may grow even larger as returns on investment decline. Here unused economies of scale are key, so that, considering only costs, consolidation is to be recommended.

The question arises, however, whether this advice should apply to pension funds of all sizes, including the very large. Economic theory typically assumes either a U-shaped average cost function or continuously decaying unit costs. Theoretical arguments and empirical evidence for the downwardsloping left leg of the $\mathrm{U}$ shape - and the left-hand part of the monotonically declining average cost function - is overwhelming. Fixed costs, being inelastic to the number of participants, account for much of the unused scale economies. Particularly information and communication technology, the basis of many pension fund activities, has strong fixed-cost components. The same holds for compliance with accounting and regulatory requirements and projects. Scale economies are also reinforced by size-related bargaining power vis-à-vis external service providers with respect to investment, outsourcing and reinsurance, and contribute further to lower unit costs (Bauer et al., 2010). Whereas fixed costs continue to decline as the size of the pension fund increases, the effect of bargaining power tends to taper off, for instance as the number of sizable counterparties declines. Commonly, large pension funds have difficulty finding competing counterparties for large interest rate swaps and other derivative transactions.

The existence of an upward-sloping right leg of the U-shaped unit cost function presupposes costs that increase more than proportionally with size. The literature provides a number of examples. Key factors are inefficiencies due to managerial problems in large, complex, international firms, as often encountered in the banking industry, 'bureaucracy', 'additional layers of management and over hiring' (see Chatterton et al., 2010), increasing luxury in terms of buildings and salaries, extra costs due to scarcity of qualified staff and additional costs related to overconfidence (Griffin and Tversky, 1992). Bauer et al. (2010) mention increasing costs of communication between the different sections of the company and the costs involved in monitoring employees, including managers. The motivation and commitment of employees may be lower in a large organization, as they contribute relatively little to the overall success of the organization, resulting in lower productivity (Canback et al., 2006). Lack of 
a clear overview of budget and liquidity in a large firm may cause inefficient spending with respect to recruitment, equipment or offices (Canback et al., 2006). Other authors point to costs due to stronger competition between units. As larger pension funds have to diversify more, they encounter more investments that lack sufficient publicly available information, leading to higher research costs (Andonov et al., 2011). And while promising higher investment returns, such investments also push up operational costs. The key question is whether such large firm inefficiencies outweigh the basic effect of the monotonically declining fixed costs.

Pension funds with large amounts of assets are unable to respond quickly to changes in the market, particularly when capital markets are stressed (McKenna and Kim, 1986; Bauer et al., 2010; Andonov et al., 2011), and therefore face market impact costs when buying or selling (Bikker et al., 2007, 2008, 2010). Dyck and Pomerski (2011) also mention that increased capital inflows lead managers to pursue poorer investment ideas. These are arguments for the simultaneous existence of diseconomies of scale, but they concern investment returns rather than operating costs.

Scale economy measures are often based on a translog cost function. This model is quadratic in nature so that it is well-suited to describe U-shaped average unit costs. However, Shaffer (1998) points out that such a cost model implies the existence of an optimal scale, as long as the cost-output size relationship is concave. He recommends the use of various cost functions with different underlying assumptions with respect to the shape of the underlying average unit cost including, in particular, models able to describe monotonically declining average unit costs. Examples are the unrestricted Laurent cost function and the Hyperbolically Augmented Cobb-Douglas model.

We apply these various cost functions on a unique data set consisting of supervisory reports by Dutch pension funds over 1992-2009, obtained from the supervisor, De Nederlandsche Bank. The huge size of the data set is of great importance as we need ample data also on large pension funds, where possible diseconomies of scale may or may not exist. Our dataset splits operating costs into administrative and investment costs. This permits us to investigate administrative and investment activities separately. Indeed, fixed and variable costs determining economies of scale vary for these different activities, while the complexity, luxury and overconfidence arguments which may affect the possible existence of an optimal scale may also diverge across activities. Note, however, that if optimal scales do exist but vary across activities, recommendations with respect to consolidation for the sake of a cost-effective market structure are more complex, because in that case trade-offs exists between the optimal scale in terms of administration and in terms of investment.

Many drivers of scale economy and optimal scale may change over time. The increasing role of ICT is likely to enlarge scale economies, as the associated costs are likely to have a substantial fixed 
component. Increasing solvency regulation and accounting requirements may also add to the fixed costs. As our dataset is large, we are able to estimate scale efficiency and optimal scale on an annual basis, so that developments over time can be investigated.

Section 2 of this paper gives an overview of the available literature on operating costs of pension funds and on the existence of scale economies. Section 3 describes the pension system of the Netherlands, while the next section analyses the data on administrative and investment costs of Dutch pension funds and presents all other data on key characteristics of pension funds. Section 5 explains the cost models considered and the measurement of scale economies. Sections 6 and 7 provide the empirical results for respectively, administrative and investment costs of pension funds. Section 8 summarizes the findings and concludes this paper.

\section{Review of the literature}

Administrative costs include all expenses involved in operating the pension fund except investment costs, and as such include costs of management and staff, communication with participants, auditing and reporting and other costs charged by third parties (as in case of outsourcing), premium collections, benefit payments, rent and depreciation. Research on pension funds' administrative costs has focused on a few countries, in particular Australia (Bateman and Valdés-Prieto, 1999; Malhotra et al., 2001; Bateman and Mitchell, 2004; Sy, 2007), the US (Caswell, 1976; Mitchell and Andrews, 1981), Chile (James et al., 2001), and the Netherlands (Bikker and de Dreu, 2009). These studies all report significant economies of scale for private pension funds. The higher cost level of small pension funds has been attributed to advantages such as higher service levels or tailor-made pension schemes (Koeleman and De Swart, 2007), but Bikker et al. (2012) have refuted this theory. Few comparative studies have been conducted across different countries, and almost none have used a multivariate approach. Whitehouse (2002) compares defined contribution (DC) schemes in 13 countries. For Latin American countries and Great Britain, the author finds no systematic relation between pension fund size and charges levied (consisting of costs and profit margins), and concludes that evidence on economies of scale in pension fund administrative cost is inconclusive. In a more recent study, Hernandez and Stewart (2008) compare the charge ratios in 21 countries with private DC schemes. The authors note that charge ratios tend to be lower in countries with fewer providers, thereby concluding that there is some evidence of economies of scale, assuming that those few pension providers are also relatively large. Tapia and Yermo (2008) conduct a similar analysis for countries where the pension system is based on Individual Retirement Accounts (IRAs): Australia, Sweden, and countries in Latin America and Central and Eastern Europe. These studies do not distinguish between investment and administrative expenses, and use charge ratios or other fee measures rather than economic costs. James et al. (2001) improve on this by comparing fees and administrative expenses 
(including investment expenses) in six Latin American countries with pension systems based on IRAs. ${ }^{1}$ The fundamental problem with this body of research is the lack of appropriate data that would allow one to determine the relative contribution of each factor in a multivariate analysis. Instead, the authors use broad descriptive statistics on the domestic pension system to highlight bivariate relationships. Only Dobronogov and Murthi (2005) conduct a multivariate cross-country study, based on a limited number of observations, and find some evidence of economies of scale in pension funds in Croatia, Kazakhstan and Poland. In general, there are large differences in administrative costs among pension funds. Some of them reflect particular market conditions or institutional environments, while others are due to different degrees of efficiency. All in all, these studies measure scale economies, but do not focus on the existence of an optimal scale.

Investment costs include investment research as well as management and consulting fees, while transaction costs and brokerage fees are excluded, as they are normally deducted from gross returns. A few studies are known about the investment costs of pension funds, while some of the above studies are on operating expenses, which include investment costs. ${ }^{2}$ Bauer et al. (2010) find for the US strong scale economies in investment costs. Costs are also higher for small cap portfolios and for portfolios which are actively managed or externally managed. Dyck and Pomorski (2011) investigate both investment costs and returns of an international sample of large pension funds. They observe significant economies of scale for both costs and returns. Most of the superior returns come from large pension funds' increased allocation to alternative investments and realizing greater returns in this asset class. Furthermore, a large literature exists on the investment costs of mutual funds. The investment operations of pension funds are similar to those of mutual funds and many pension funds invest assets through mutual funds. Therefore, this literature can provide meaningful insights into the investment operations of pension funds as well. ${ }^{3}$ Empirical evidence suggests the existence of substantial costrelated economies of scale in the mutual fund industry (e.g. Malhotra and McLeod, 1997). However, these turn out to decrease as the fund size increases and become zero as soon when the optimal size has been reached (e.g. Indro et al., 1999, and Collins and Mack, 1997). Of course, mutual funds may incur higher costs hunting for higher returns. Ippolito (1989) compares the expenses and returns of mutual funds and index funds and found that mutual funds offset higher expenses with better results. Possibly, however, this outcome may be sensitive to the particular benchmark used, or be explained by survivorship bias (e.g. Malkiel, 1995). Many other studies have found that higher costs are not related

\footnotetext{
${ }^{1}$ Note that the data set in this study contains pure economic costs.

${ }^{2}$ Caswell (1976), Bateman and Mitchell (2004), Dobronogov and Murthi (2005), and Mitchell and Andrews, (1981) use total costs. Only James et al. (2001) report separate statistics on investment fees for some individual account pension schemes.

${ }^{3}$ Mutual fund expenses and investment costs of pension funds are different. For example, marketing costs and administration costs are important cost categories in the mutual fund industry. Pension funds have little if any marketing costs and administration costs are reported separately. Also, pension funds have to take the duration of their investment portfolio into account, given their liabilities. Finally, mutual funds often focus on investments in one asset class (e.g. stocks, bonds), while pension funds generally invest in various asset classes.
} 
to superior performance relative to the risk-adjusted rate of return (e.g. Jensen, 1968, Malkiel, 1995, and Malhotra and McLeod, 1997). Thus, the evidence suggests that, in general, higher costs incurred by mutual funds do not lead to higher returns. Since the investment operations of pension funds and mutual funds are similar, it seems reasonable to expect this result to hold for pension funds as well. ${ }^{4}$ We may therefore conclude that, ceteris paribus, stakeholders are likely to be best served by pension funds with low investment costs. We conclude that, on the investment market, scale economies tend to exist but, according to some studies, only as long as institutions are below the optimal scale.

\section{The pension system in the Netherlands}

As in most developed countries, the institutional structure of the pension system in the Netherlands is organized as a three-pillar system. The first pillar comprises the public pension scheme and is financed on a pay-as-you-go base. It offers a basic flat-rate pension to all retirees and aims to link the benefit level to the legal minimum wage. The second pillar provides former workers an additional income from a collective, contribution-based supplementary scheme. The third pillar comprises tax-deferred personal savings, which individuals undertake at their own expense. The supplementary or occupational pension system in the Netherlands is usually organized as a funded defined-benefit (DB) plan. The benefit entitlement is determined by years of service and a reference wage, which may be final pay or the average wage over the years of service. The defined-benefit formula takes the public scheme into account.

Supplementary schemes are usually managed on a collective basis by pension funds. There are three types of pension funds. The first type is the industry pension fund, which is organized for a specific industry sector (e.g. construction, health care, transport). Participation in an industry pension fund is mandatory for all employers operating in the sector, with a few exceptions. ${ }^{5}$ An employer may opt out if it establishes a corporate pension fund that offers a better pension plan to its employees. Where a supplementary scheme is agreed by employers and employees, managed by either a corporate pension fund or an industry pension fund, participation by the workers is mandatory, governed by collective labour agreements. The third type of pension fund is the professional group pension fund, organized for a specific group of professionals, such as the medical profession or notaries.

The Dutch pension fund system is highly comprehensive, covering as much as $92 \%$ of the active labour force in 2010. Almost all employees are covered, but the self-employed need to arrange their

\footnotetext{
${ }^{4}$ Lakonishok et al. (1992) report that the pension fund industry has consistently underperformed the market. The authors put forward that pension fund managers may trade too much, incurring large execution and transaction costs, and may be unlucky with their timing.

${ }^{5}$ Collective labour agreements do not always attain the legally compulsory industry-wide status and if attained, this status expires if the investment returns on pension assets do not meet minimum levels.
} 
own old-age savings. At the end of 2011, total pension fund assets in the Netherlands amounted to some $€ 830$ billion, or $138 \%$ of GDP, ranking the Dutch pension system, in terms of the assets-to-GDP ratio, as the largest in the industrial world. ${ }^{6}$

\section{Key characteristics of Dutch pension funds}

The data used in this paper were obtained from De Nederlandsche Bank (DNB), supervisor of the Dutch pension fund industry. We have annual data for the 1992-2009 period and, in addition, quarterly data on investments starting 1999. Fig. 4.1 presents the development of pension fund numbers and types over time. The number of pension funds declined from around 880 during 19931998 to 550 in 2009. Some eighty per cent of the discontinued pension funds handed over their assets and liabilities to insurers, the rest have merged. Most of the dissolved funds were small, half of them numbering fewer than 250 participants. In total, we have a sample of close to 13 thousand annual pension fund observations.

Fig.4.1. Number of pension funds over time and by governance type

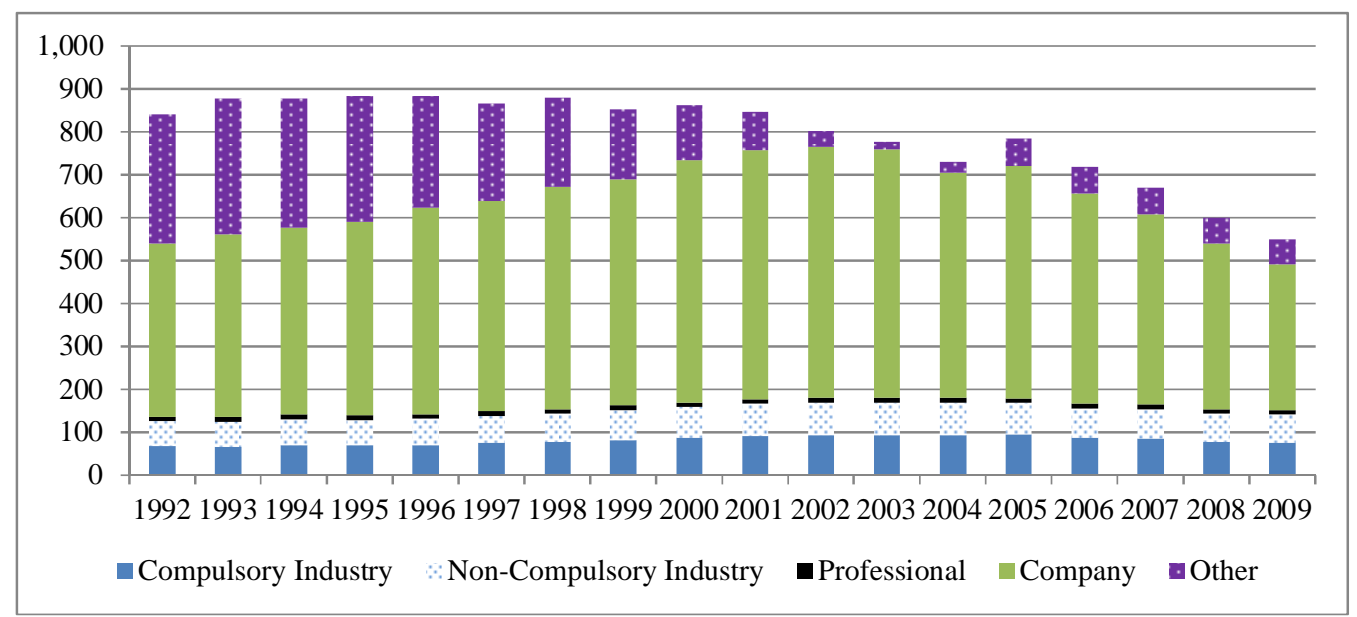

Company funds are largest in number, followed by compulsory industry funds, non-compulsory industry funds and professional group funds (Fig. 4.1). However, Table 4.1 in Section 4.2 makes clear that in terms of participants, compulsory industry funds dominate the pension sector with, in 2009, a share of $84 \%$, followed by company funds $(13 \%)$.

\footnotetext{
${ }^{6}$ Fig. 5 in OECD (2011; see page 7) shows for 2010 that the asset-to-GDP ratio of the pension sector is higher in the Netherlands than in all other OECD countries.
} 


\subsection{Operating costs}

Operating costs (OC) consist of administrative costs and investment costs. Administrative costs regard the collection of contributions, record keeping, benefit payments, communications, accounting and marketing, while investment costs refer to portfolio management, financial research, trading facilities and advice. Transaction fees and management fees of mutual funds are not included, as they are normally already deducted from the investment returns. We split OC into administrative and investment costs, because each has different characteristics and distinct determinants. Fig. 4.2 presents the administrative cost per participant for the 2,000 non-zero observations over 2006-2009. In this paper, all value amounts are expressed in prices of 2004. We recognize the left (downward sloping) leg of the U-shaped average cost per unit curve, although particularly for the smaller pension funds, the spread within each size class is huge. Note that in this graph costs of over $€ 1,000$ per participant have been deleted to simplify the presentation. Gradually, for the larger pension funds (say over 35.000 participants) $)^{7}$ the costs decline across the board. The increase in cost in the right hand tail is remarkable. It suggests either diseconomies of scale for the really large funds (over 165 thousand participants $)^{8}$ and pointing to the existence of an optimal scale, or at least an upper limit to unused economies of scale.

Fig. 4.2. Administration costs per participant across pension funds (2006-2009; 2004 prices)

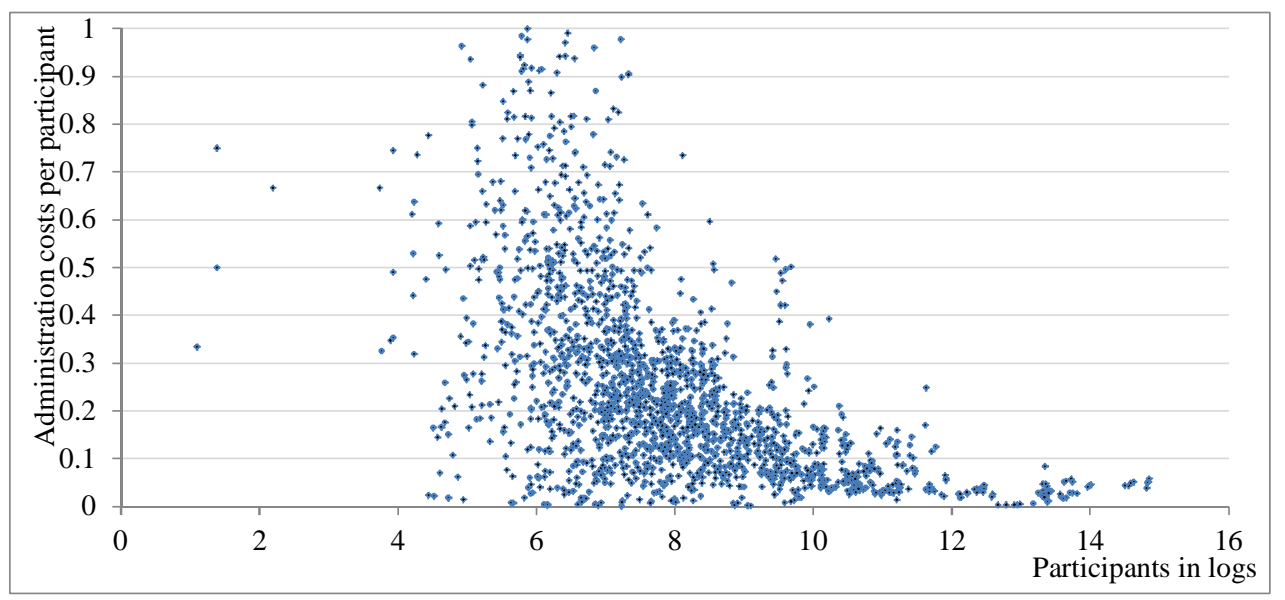

Fig. 4.3 repeats the administration costs per participant in 2006-2009, but now expressed as averages over ten size classes with for each class the spread in average costs. ${ }^{9}$ The median costs per participant decline strongly from $€ 666$ in the smallest class to $€ 39$ in the largest class. The spread in costs per

\footnotetext{
${ }^{7}$ In logarithms, larger than 10.5 .

${ }^{8}$ In logarithms, larger than 12.

${ }^{9}$ Borders of the size classes are, in terms of number of participants: 280, 525, 850, 1300, 1900, 3000, 5000, 11000 and 35,000 .
} 
participant is immense, particularly in the smallest size class, ranging from $€ 75$ to $€ 4,000$ (respectively, the $10^{\text {th }}$ and $90^{\text {th }}$ percentiles), but also in the largest size class, ranging from $€ 14$ to $€$ 118. Of course, the largest class - containing $90 \%$ of the participants - is most important. Splitting this class into 5 or 10 subclasses would reproduce the same declining graph with reducing spread. Figure 4.2 for the three earlier subperiods 1992-1996, 1997-2001 and 2002-2005 would look similar. The same applies to Figure 4.3, with the only exception that the graphs for earlier periods start at a higher level for the smallest class and are flatter for the medium-sized classes.

Fig. 4.3. Administration costs per participant in size classes (2006-2009; 2004 prices)

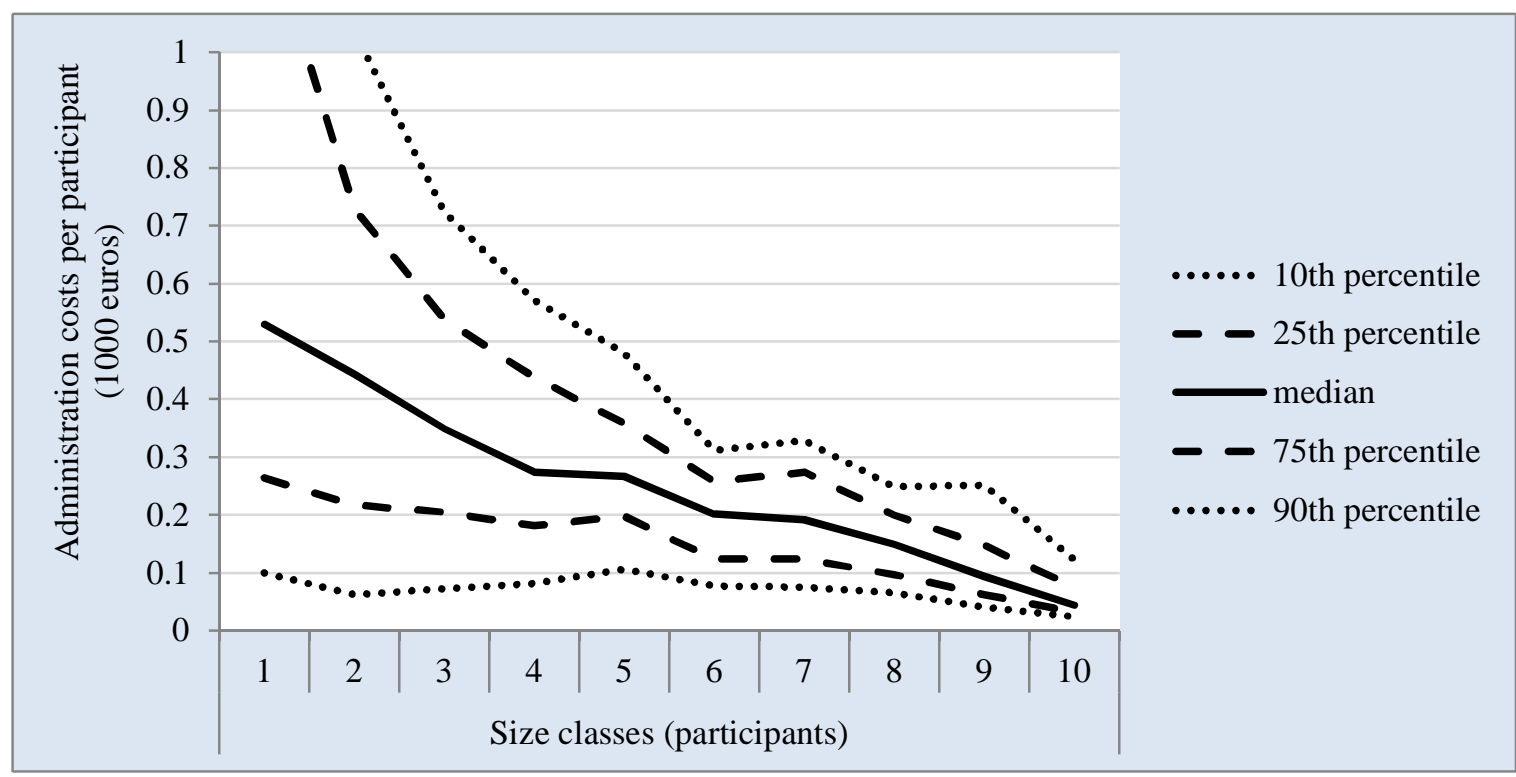

Note that the median and the lower bounds may underestimate the costs due to possible underreporting. Some companies pay for the administration and investment activities of their own pension funds without on-charging salaries and office costs, leading to zero or lower reported costs (Bikker and De Dreu, 2009). Such underreporting is found especially for smaller pension funds. ${ }^{10}$ In Section 6, where we discuss estimation results, we will prove that - due to underreporting - scale economy may be even stronger than we observe, so that our estimates establish a lower bound.

Fig. 4.4 presents the investment costs as share of total assets for the 1,650 non-zero observations over 2006-2009, a lower number than for administration costs. Many funds report zero investment costs as many as ca. $64 \%$ in 1992-1996, falling to $29 \%$ in 2006-2009 (see Table 4.2 below, the 'reporting investment costs dummy'). In many cases, investment costs are hidden in the investment returns, which are (incorrectly) reported net of costs rather than gross. Underreporting of investment costs is

\footnotetext{
${ }^{10}$ Mitchell (1998) observed the same phenomenon in Australia.
} 
most frequent among the smaller funds. ${ }^{11}$ In Section 7, where we discuss estimation results, we will also discuss the impact of underreporting.

We hardly recognize the left leg of the U-shaped (or L-shaped) average cost per unit curve, although the upper border is monotonically declining: the spread within each size class dominates. Note that investment costs above $1 \%$ of total assets have been omitted for the sake of presentation. For investment costs, we do not see an increase in costs at the right-hand tail, as in Fig. 4.2.

Fig. 4.4. Investment costs as share of total assets across pension funds (2006-2009; 2004 prices)

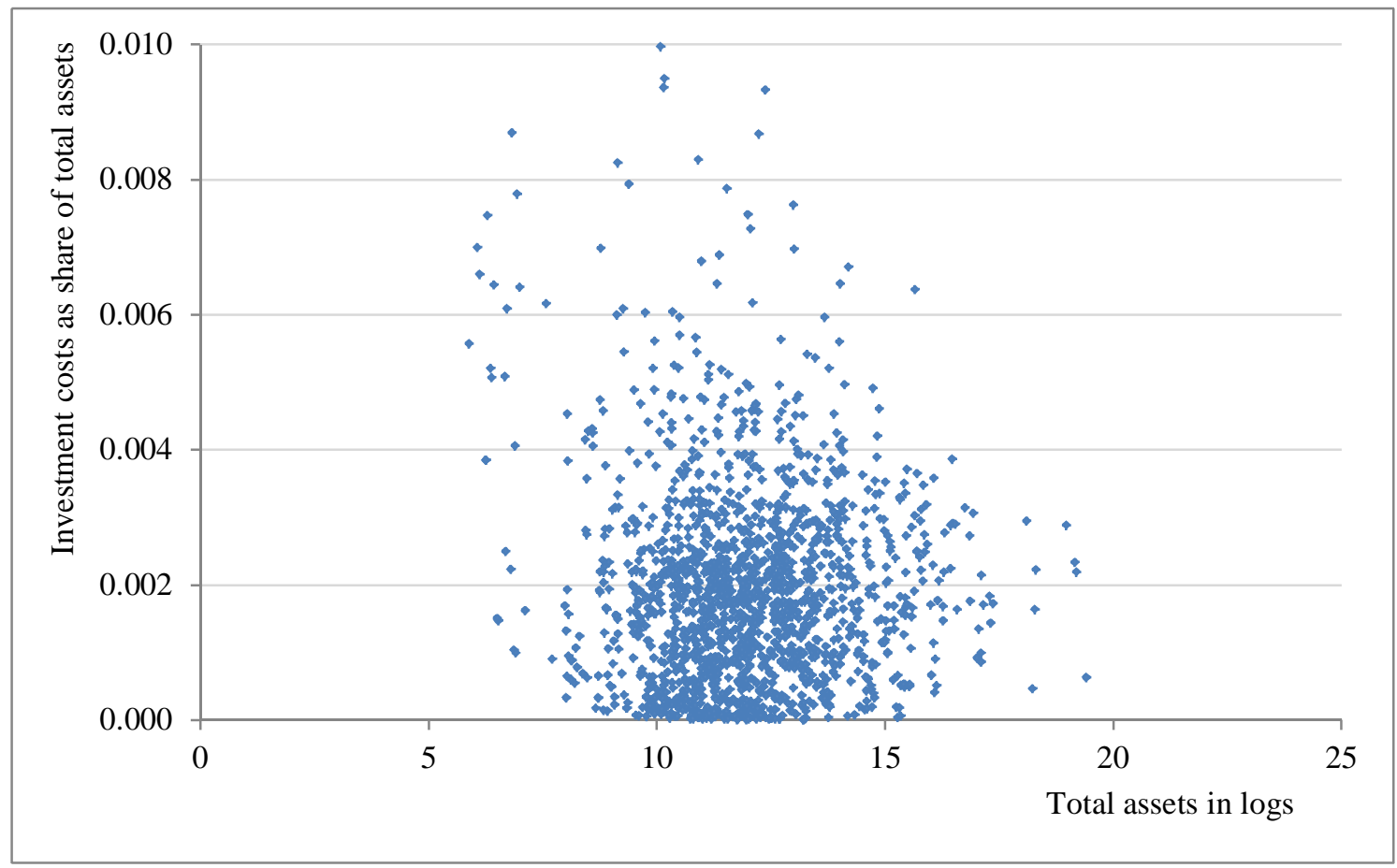

For 2006-2009, Fig. 4.5 shows investment cost as share of total assets expressed as medians over ten size classes with for each class its spread. ${ }^{12}$ Scale economies seem to be absent, except possibly for the smallest size class. This is not representative for the three earlier periods (see the first row of Table 4.1), where median costs in the smallest size class were, respectively, 2.5, 2 and 1.5 times larger than in the largest size class (compared to no less than 31, 29, 15 and 12 times for administration costs). Also remarkable is the fact that the spread in investment costs is constant across the size classes (apart from a higher level in the first size class), without the convergence for larger classes as observed for

\footnotetext{
${ }^{11}$ We expect that some of the funds that do not report (all) investment costs include them (in part) in their administrative costs. To test this assumption - and to correct for such misreporting - we define a dummy variable 'reporting of investment costs', with 1 for pension funds with positive investment costs and 0 for nonreporting funds, as an explanatory variable in the administration costs model. A negative coefficient would indicate, and roughly correct for, misreporting.

${ }^{12}$ Borders of the size classes, in terms of total assets, are at 15, 35, 55, 85, 140, 210, 350, 650 and 1,750 million euros.
} 
administrative costs. Of course, the largest class - containing $85 \%$ of total assets - is of most importance. Splitting this class in 5 or 10 subclasses would show an increase in investment costs for the largest funds.

Fig. 4.5. Investment costs as share of total assets (2006-2009; 2004 prices)

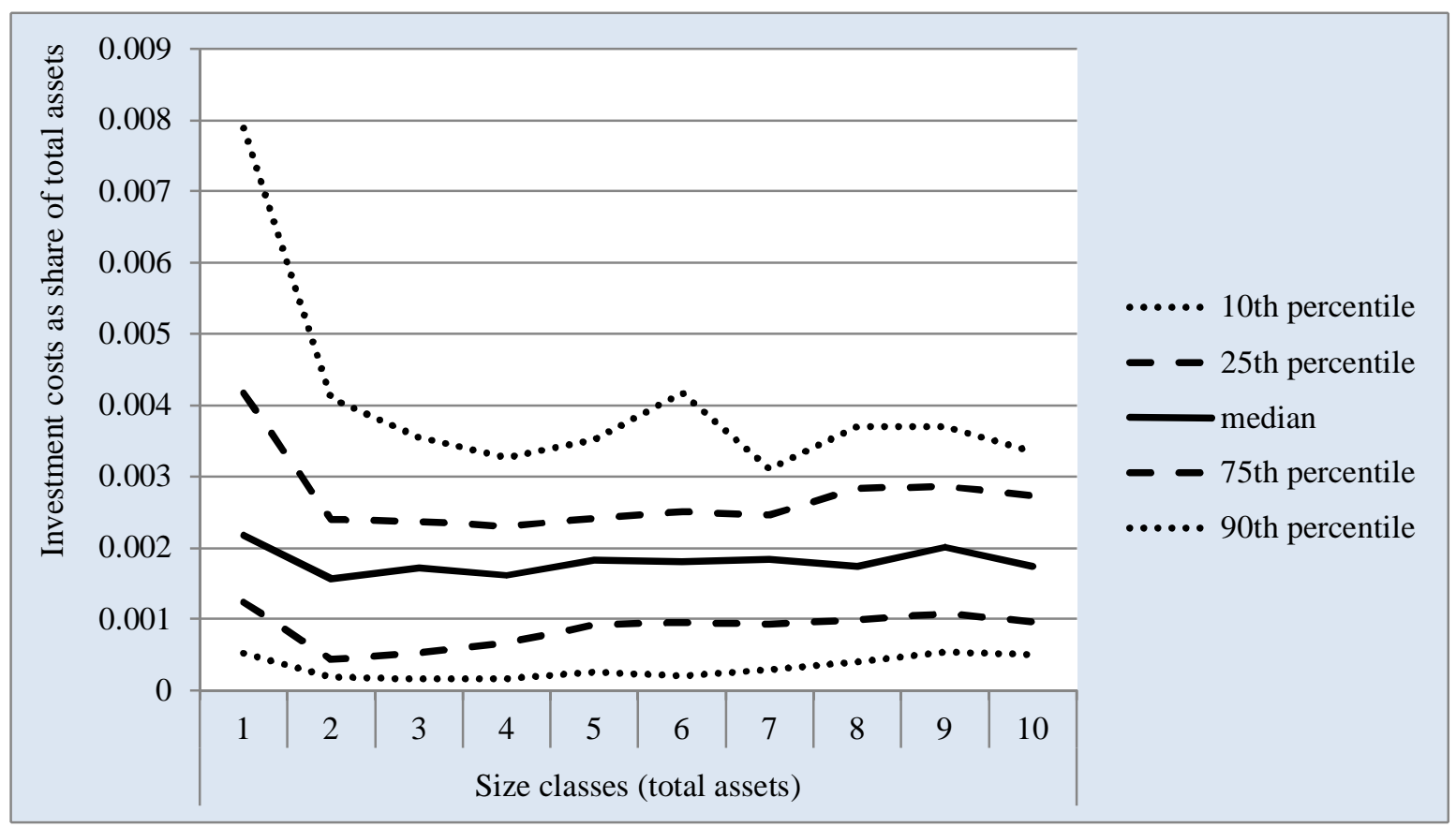

We believe that two phenomena interact here: scale economies (which must exist given the presence of fixed costs) and the higher relative shares of complex assets in larger pension fund portfolios, with higher investments costs but correspondingly higher expected returns. Fig. 4.6 shows how larger pension funds' portfolios have higher relative shares of commodities, hedge funds, private equity and real estate, which all are expected to go with higher costs, whereas the smallest pension funds tend to prefer other (simpler) assets such as money market funds. As we have the asset allocation by pension fund, regression analyses can disentangle the economies of scale effect from the size-dependent investment composition effect.

\subsection{Other key data of Dutch pension funds}

This subsection presents key characteristics of Dutch pension funds, which will act as control variables in the operating cost models. The first rows in Table 4.1 show that administrative costs per participant increase over time by over $50 \%$, reflecting the rise in real wages $(21 \%)$ and the costs of new activities related to new requirements as regards communication to participants, solvency and accounting regulation, et cetera. Underreporting of administrative costs, particularly salaries, has decreased over time, which contributes to higher (reported) costs. Investment costs doubled over time, and increased especially during the last years, mainly due to additional investment costs for high-risk 
assets, e.g. hedge funds, commodities and private equity. Here, declining underreporting over time is also a major factor.

Fig. 4.6. Pension fund asset allocation across size classes in 2009

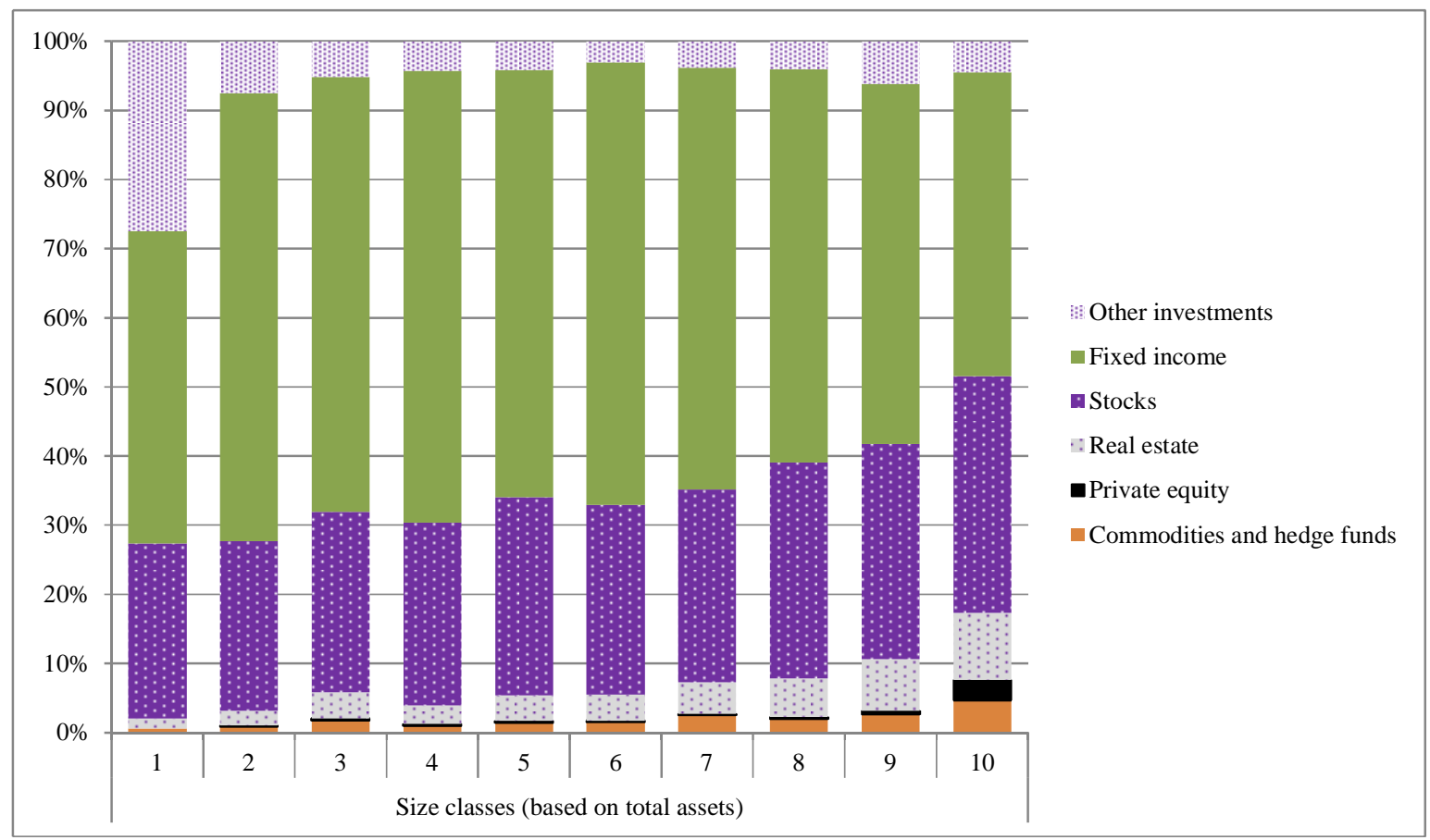

The total number of participants increased strongly over time from 9.7 to 17.5 million, due to increased employment (less unemployment and greater participation, in part due to an increase in parttime jobs), greater coverage, and joining in the sample of the largest pension fund in 1996. This public servants' pension fund ('Algemeen Burgerlijk Pensioenfonds') has, in 2009, 2.8 million participants and total assets amounting $€ 208$ billion. The size distribution of the pension funds is very skew, as the $10 \%$ smallest pension funds have, on average, only 125 participants and total assets of, on average, $€ 7$ million. Total assets increased strongly over time as well, from $€ 200$ to 700 billion, reflecting growth in volume (participants) and in wealth (both income and building-up level). There are two basic types of pension scheme: (mainly) Defined Benefit (DB) and (mainly) Defined Costs (DC), where schemes of both types may have some mixed (DB and DC) characteristics. ${ }^{13}$ Falling from 4\% in 1992 to in $1 \%$ in 1998, the share of DC increased sharply to $9 \%$ in 2008 and 2009. There are three categories of participants exist: active, inactive, and retirees. Each category increased in number, while their shares remained fairly constant. The variable 'total assets per participant' reflects whether a pension fund has relatively high per capita assets and, hence, higher than average benefits. ${ }^{14}$ Where we consider the

\footnotetext{
${ }^{13}$ A DB pension fund pays a defined annual amount to the participant at retirement, often a percentage of the average (or, in earlier years, final) wage. The DC participant pays a defined annual premium while working and the pension pay-out is based on premiums and investment returns.

${ }^{14}$ It may also reflect a higher level of asset accumulation, associated with a more mature fund.
} 
number of participants as output measure for the administration cost model, 'total assets per participant' introduces the impact of the second output dimension: total assets. Similarly, where we consider total assets as output measure for the investment cost model, 'total assets per participant' introduces the impact of the first output dimension, namely, number of participants.

Table 4.1. Key data of Dutch pension funds over time (prices of 2004)

\begin{tabular}{|c|c|c|c|c|}
\hline & 1992-1996 & 1997-2001 & $2002-2005$ & 2006-2009 \\
\hline Administration costs per participant, in euros ${ }^{a}$ & 37.24 & 48.95 & 50.92 & 54.16 \\
\hline Investment costs per participant, in euros ${ }^{\mathrm{a}, \mathrm{b}}$ & 16.26 & 20.73 & 32.40 & 68.59 \\
\hline Investment costs/total assets, in $\%{ }^{\mathrm{a}, \mathrm{b}}$ & 0.09 & 0.06 & 0.10 & 0.19 \\
\hline Number of participants, in millions (p) & 9.70 & 13.43 & 16.27 & 17.54 \\
\hline Total assets, in billion euros & 207.75 & 469.87 & 526.84 & 654.63 \\
\hline Liabilities, in billion euros & 180.00 & 362.77 & 457.97 & 530.13 \\
\hline Real wages pension industry (thousand euros) & 55.27 & 57.01 & 63.69 & 66.80 \\
\hline Compulsory industry pension fund part./p & 0.81 & 0.82 & 0.82 & 0.84 \\
\hline Company pension fund participants/p & 0.12 & 0.13 & 0.14 & 0.13 \\
\hline Non-compulsory industry pension fund part./p & 0.02 & 0.02 & 0.03 & 0.01 \\
\hline Professional group pension fund participants/p & 0.01 & 0.00 & 0.00 & 0.00 \\
\hline Other pension fund participants/p & 0.05 & 0.02 & 0.01 & 0.01 \\
\hline Pension scheme: DC participants/p & 0.03 & 0.02 & 0.05 & 0.08 \\
\hline Retirees/p & 0.13 & 0.14 & 0.14 & 0.15 \\
\hline Active participants/p & 0.36 & 0.38 & 0.37 & 0.33 \\
\hline Inactive participants/p & 0.51 & 0.47 & 0.49 & 0.52 \\
\hline Assets per participant (thousand euros) ${ }^{a}$ & 21.41 & 35.00 & 32.37 & 37.33 \\
\hline Reporting investment costs dummy ${ }^{\mathrm{a}}$ & 0.36 & 0.50 & 0.69 & 0.71 \\
\hline Outsourcing/administration costs ${ }^{a}$ & 0.51 & 0.53 & 0.77 & 0.65 \\
\hline Reinsurance premiums/total premiums ${ }^{\text {a }}$ & 0.10 & 0.04 & 0.01 & 0.03 \\
\hline Fixed income/total investments (ti) ${ }^{\text {a, c }}$ & 0.56 & 0.47 & 0.46 & 0.47 \\
\hline Investments in stocks/ti ${ }^{\text {a }}$ & 0.24 & 0.41 & 0.40 & 0.38 \\
\hline Real estate $/ \mathrm{ti}^{\mathrm{a}}$ & 0.12 & 0.10 & 0.10 & 0.10 \\
\hline Other assets/ti ${ }^{\text {a, }} \mathrm{d}$ & 0.07 & 0.02 & 0.03 & 0.05 \\
\hline Private equity/ti ${ }^{\text {a }}$ & 0.00 & 0.01 & 0.02 & 0.03 \\
\hline Commodities/ti ${ }^{\text {a }}$ & - & 0.00 & 0.01 & - \\
\hline Hedge funds and commodities/ti ${ }^{a}$ & - & - & - & 0.04 \\
\hline
\end{tabular}

Note: Variable names are abbreviated within brackets: number of participants is $\mathrm{p}$ and 'total investments' is ti.

${ }^{a}$ On average; ${ }^{b}$ To avoid the problem over underreporting, we take averages over non-zero investment costs (ic) only, while the variable total assets in this row refers to the sum over the pension funds where ic are non-zero; ${ }^{\mathrm{c}}$ Total investment is 5 percent smaller than total assets, the difference being one-off items; ${ }^{\mathrm{d}}$ This variable is used in the regressions only for 19921996, as for later years is has been split into - among other things - commodities and hedge funds.

Many pension funds outsource their administration partly or fully. Especially small funds can benefit from outsourcing, as companies specializing in administrative work for many pension funds can work on a large scale and, hence, are expected to be relatively efficient. Note that where sponsor companies bear a part of their funds' administrative costs, such underreporting of costs stops as soon as outsourcing begins. Hence, outsourcing may either pick up cost reduction (negative coefficient) as well as reduced underreporting (positive coefficient). Our variable describes the percentage of costs paid to third parties. The level of outsourcing is high at more than $50 \%$ of administrative costs, increasing over time, but falling more recently. Remarkably, larger pension funds outsource relatively more than smaller ones, probably because smaller pension funds rely on administrative work by the sponsor company. Reinsurance of pension fund liabilities by an insurer is measured as the reinsurance 
premiums in proportion to total pension premiums. Reinsurance declined over the years from $10 \%$ to $3 \%$, probably because many small funds have been replaced entirely by collective insurance policies.

Pension funds invest in assets such as fixed-income securities, stocks, real estate, participations or private equity, commodities, hedge funds, mortgages and money-market funds. First, we have data on the first three categories (as well as 'other assets') from the annual reports of pension funds over 19922009. Table 4.1 shows an increase in stocks during the first half of the sample period, at the cost of fixed-income securities. Second, we have data on investments in private equity, commodities and hedge funds from the quarterly reports starting in 1999. Hedge fund investments have only been reported since 2007. Definitional breaks - the split in 1999 of other assets into private equity and commodities, and the split in 2007 of commodities into commodities and hedge funds - are dealt with in the empirical models. The more complex assets are expected to go with higher costs, as they are more difficult to understand and more expensive to manage. Generally, the expected returns of such more risky assets are higher, ex ante at least offsetting the extra costs. During the last couple of years the riskier investment classes such as private equity, commodities and hedge funds became more and more popular with pension funds (Table 4.1; Bauer et al., 2010). Hence a significant influence is expected on the investment costs of the pension funds that do use these risky investment classes. These assets are held by the largest funds: in 2009, the largest pension funds held 5\% hedge funds and $3 \%$ private equity versus, respectively, $2 \%$ and $0.5 \%$ for other funds (see also Fig. 4.6). Using the investment shares in stocks, real estate, private equity, commodities, hedge funds and other funds, we aim - in our model - at correcting the investment costs for rewarding activities in these risky asset categories.

For almost all variables, while variation over time may be generally modest (Table 4.1), variation across pension funds is generally huge (as illustrated for costs in Figures 4.2-4.5), so that controlling for such variation - when measuring scale economies - is crucially important.

\section{Functional forms of operating cost models}

This section discusses the functional form of various well-known cost models and the underlying assumptions with respect to the shape of the average cost per unit curve, which have a major impact on the existence and magnitude of an optimal scale. Next, we develop empirical models for administrative costs. Furthermore, this section explains the measurement of economies of scale.

\subsection{Functional form and optimal size}

The measurement and analysis of differences in pension fund cost levels is based on the assumption that an individual pension fund's production technology can be described by a production function, 
which links the various types of pension fund output to input factor prices, such as wages, housing rent, and so on. Under proper conditions, a dual cost function can be derived, using output levels and factor prices as arguments (Coelli et al., 1998, p. 43-49). In the literature, the translog cost function (TCF) to describe costs dominates other model specifications. Christensen et al. (1976) proposed the TCF as a second-order Taylor expansion, usually around the mean, of a generic function with all variables appearing as logarithms. This TCF is a flexible functional form that has proven to be an effective tool for the empirical assessment of efficiency, both in banking and elsewhere (Christensen et al., 1976; Dietsch, 1993; Nauriyal, 1995; Edirisuriya et al., 2001). It is an extension of the CobbDouglas function which is capable of fitting U-shaped average cost functions. ${ }^{15}$ A simple TCF reads as follows:

$\ln O C(o)=\alpha+\beta_{1}(\ln o)+\beta_{2}(\ln o-\overline{\ln o})^{2}$

with $O C$ for operating costs and ' $O$ ' for output volume. Note that, in the squared term, we take the logarithm of output in deviation from its mean (denoted by the bar above the variable), in line with the Taylor expansion. ${ }^{16}$ Here, we assume only one output measure for the expository simplification, but we consider more output measures in the empirical sections. In that case the model is extended with cross terms from both output measures. Since the Netherlands is a relatively small country, we expect little or no variation in input prices. (Swank, 1996) Actually, pension funds do not report data on input prices, so that we are also unable to include pension fund specific prices in the cost functions. We do, however, include an index of real wages in the pension sector to pick up input price effects over time. ${ }^{17}$ Unused scale economies exist where $\beta_{l}<0$, while concavity, or a U-shaped average cost function, requires $\beta_{2}>0$.

Shaffer (1998, page 94) proves that for a sample of monotonically declining average costs the TCF would estimate a concave function with an optimal scale, so that the existence of an optimal size and diseconomies of scale for larger firms is (incorrectly) imposed. ${ }^{18}$ Indeed, the left leg of the TCF can be fitted to the hyperbolically declining average costs, with the optimal scale in the right-hand tail of the sample, or beyond the largest observation. Therefore, Shaffer (1998) suggests two additional cost functions to estimate scale economies which do not impose this $\mathrm{U}$-shaped average-cost function.

\footnotetext{
${ }^{15}$ For shortcomings of the TCF, see Shaffer (1998, p. 91).

${ }^{16}$ White (1980) and Shaffer (1998, p. 95) explain that this specification also helps to avoid multicollinearity. Note that $\overline{\ln o}$ is the arithmetic average of the logarithms of output measure $o_{i}$.

${ }^{17}$ To simplify the presentation, we do not include the price index in Eq. (5.1). Normally, a TCF would also include cross terms between output and input prices. Dropping input prices and other output measures implies that no cross terms remains.

${ }^{18}$ Except possibly over limited ranges of scale within which marginal costs are steeply declining.
} 
The first alternative is the unrestricted Laurent function (ULF), which is similar to the TCF, but with two inverse terms added:

$\ln O C(o)=\alpha+\beta_{1}(\ln o)+\beta_{2}(\ln o-\overline{\ln o})^{2}+\beta_{3} /(\ln o)+\beta_{4} /(\ln o)^{2}$

The ULF can describe monotonically declining average cost, does not impose an optimal scale and allows different degrees of concavity for smaller and larger pension funds. For the concave properties to hold, the coefficients $\beta_{3}$ and $\beta_{4}$ should both be positive, next to $\beta_{2}$. According to Shaffer (1998), the improvement of the ULF over the TLF may die down for skewed size, because the squared nature of the cost-output relationship is built up by the relatively large share of observations in the smaller size region of the data sample. Therefore, he proposes a second alternative: the hyperbolically-adjusted Cobb Douglas (HACD) cost function, see also Adanu et al. (2009). This model reads as (again ignoring input prices):

$\ln O C(o)=\alpha+\beta_{1}(\ln o)+\beta_{2} / o$

Thanks to the additional reciprocal term, this model can portray the $\mathrm{U}$-shaped average cost function $\left(\beta_{1}>\beta_{2}\right)$, monotonically declining average costs $\left(\beta_{1}>1\right.$ and $\left.\beta_{2}>0\right)$ and the L-shaped average cost function $\left(\beta_{1}<1\right)$. To investigate which functional form best suits the sample data, we will apply Akaike's (1974) information criterion (AIC). In a simulation test by Shaffer (1998) on generated data, this HACD model performed best.

Cost elasticity $(C E)$ is defined as the proportional increase in cost as a result of a proportional increase in output. In mathematical terms this results in the following expression for elasticity:

$C E=\partial \ln O C / \partial \ln o$

Using Eq. 5.1-5.3, this results in, for the TCF, the ULF and the HACD respectively:

$$
\begin{aligned}
& C E^{\text {tcf }}=\beta_{1}+2 \beta_{2}(\ln o-\overline{\ln o}) \\
& C E^{u l f}=\beta_{1}+2 \beta_{2}(\ln o-\overline{\ln o})-\beta_{3} /(\ln o)^{2}-2 \beta_{4} /(\ln o)^{3} \\
& C E^{\text {hacd }}=\beta_{1}-\beta_{2} / o
\end{aligned}
$$


The second term of the $C E s$ in the TCF and the ULF becomes zero when the $C E s$ are evaluated around the mean of the sampled logarithms of output $\underline{o_{i}}$, that is: $\overline{\ln o}$. The $C E$ for the TCF is then equal to $\beta_{1}$, while for the ULF and the HACD, it depends on the sample observations. ${ }^{19}$

The scale economies $(S E)$ can easily be calculated from the above by subtracting EC from unity: $S E=1-E C$. If the calculated $E C$ has a value larger than one, this indicates diseconomies of scale; a value smaller than one indicates economies of scale and a value of exactly one indicates constant returns to scale. To calculate a possible optimal pension fund size, a value for $o$ has to be found to set $C E$ equal to one (or to set $S E$ to zero).

\subsection{Empirical model for administrative costs}

This section specifies empirical models for administrative costs $(A C)$, in logarithms, based on, respectively, the TCF, the ULF and the HACD functions. The TCF reads as:

$\ln A C_{i t}=\alpha+\beta_{1}\left(\ln\right.$ participants $\left._{i t}\right)+\beta_{2}\left(\ln \text { participants }_{i t}-\overline{\ln \text { participants }^{2}}\right)^{2}+\gamma_{1} \ln$ real wage $_{t}+$ $\gamma_{2}$ governance dummies $_{i t}+\gamma_{3}$ pension plan design $_{i t}+\gamma_{4}$ type of participants $_{i t}+\gamma_{5}$ assets per

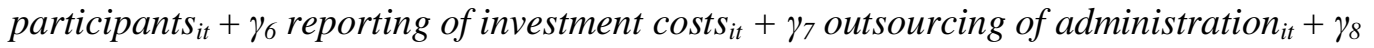
reinsurance $_{i t}+\gamma_{9}$ time $_{t}+\varepsilon_{i t}$

Subindex $i$ refer to pension funds, while $t$ refers to time. Output is measured as number of participants as many administrative activities are related to services provided to participants, mainly irrespective of the size of their pension benefits. Output is expressed in logarithms and appears linear and squared, the latter in deviation from its mean, in line with Eq. (5.1). Real wages is a wage index for the pension and insurance sector which acts as an input price. Its coefficient is expected to be positive. Governance dummies indicate, respectively, compulsory industry pension funds, company funds, professional group funds, and other funds, while compulsory industry funds act as the benchmark. These dummies may pick up cost differences across pension fund types. The pension plan design dummy indicates pension funds with defined-benefit (DB) plans reflecting cost differences with the remaining category: defined contribution (DC) funds. Three types of participants are distinguished: active participants, inactive participants and retirees, each of which may carry different costs, as administrative activities differ by type of participant. These variables are expressed as shares in the total number of participants. The share of active participants acts as benchmark. Total assets per participant measures whether administrative cost may increase with (future) pension benefits. The dummy variable for reporting of investment costs tests for incorrect reporting of investment costs under administrative

\footnotetext{
${ }^{19}$ For the reciprocal terms in the ULF we replace ln $o$ by the geometric mean of the output term. For the reciprocal term in the HACD model, arguments (to replace $o$ ) exist for both the geometric and arithmetic mean. This choice has no further consequences.
} 
costs. Costs of outsourcing as share of totals administration costs may reflects costs differences.

Reinsurance premiums as share of total premiums may pick up costs (other than premiums) related to reinsurance. Finally, time may reflect technical progress over time.

The ULF is based on Eq. (5.7) expanded with $\beta_{3}(1 / \ln$ participants $)+\beta_{4}\left(1 /(\ln \text { participants })^{2}\right)$, while the HACD cost model is equal to Eq. (5.7), where the $2^{\text {nd }}$ output term is replaced by $\beta_{2}$ (1/ participants). Deviations from the mean in the reciprocal terms would not make sense, e.g. values of zero (or close to zero) in the inverse terms would distort the equations.

\section{Empirical results for administrative costs}

This section displays the estimation results of the three different cost functions, both for the entire data sample as for each year separately. The full sample regressions combine all available information, resulting in highly significant results, while the single year regressions take into account changes over time. Table 6.1 shows the estimations of the administrative cost model for three cost functions using the full dataset of all Dutch pension funds over 1992-2009, consisting of 12,521 observations. ${ }^{20}$ The upper panel of the table shows the estimated coefficients, the middle panel presents estimation and test statistics, and the lower panel displays the first derivatives (or $C E$ ), the optimal scale and the cost elasticities at the mean size values of the pension funds.

\section{Translog cost function}

We first discuss the results of the three models with respect to the cost-output relationship and then compare them. Subsequently, we consider the coefficients of the other explanatory variables. The cost elasticity is 0.717 , calculated at (the logarithm of) the geometric mean of 936 participants, that is $\log$ (936). ${ }^{21}$ If the number of participants increases by $1 \%$, total administrative costs will increase by only $0.72 \%$. This implies huge scale economies of $28 \%$. The cost elasticity is higher here than the 0.64 found by Bikker and De Dreu (2009) for the Netherlands over 1992-2004, which means that the extent of scale economies is lower, while the opposite is true when comparing to the 0.76 of Bikker et al. (2012) found in a four-country comparison over 2004-2008. ${ }^{22}$ The relationship between administrative costs and total participants is concave (coefficient of the squared term is 0.021 ): scale

\footnotetext{
${ }^{20} 336$ pension funds are legal vehicles for directors-large shareholders and director funds for board members and supervisory board members with only one participant. They have been deleted as these pension funds are not representative and, moreover, their size would not fit into the inverse terms of the ULF (which would, respectively, be equal to $1 / \ln (0)$ and its square).

${ }^{21}$ Pension funds with one participant have been excluded. The arithmetic mean is 19,991 participants. See Eq. (5.4-5.6) for the cost elasticities of the three models. The cost elasticity in the TCF is equal to the coefficient of its linear output term. In general, this does not hold for the HACD model, except in our sample where the nonlinear output coefficient is (at 2.502) small compared to the arithmetic average number of participants $(19,991)$.

${ }^{22}$ In their sample of large pension funds, these authors did find the same cost elasticity $(0.69)$ for the Netherlands.
} 
Table 6.1. Estimates of the administrative cost models (1992-2009)

\begin{tabular}{|c|c|c|c|c|}
\hline Variable & Translog & $\begin{array}{l}\text { Unrestricted } \\
\text { Laurent function }\end{array}$ & HACD & Simplified ULF \\
\hline Participants (in logarithms) & $0.717 * * * 1000$ & $0.781 * * * 1000$ & $0.748 * * * 1000$ & $0.726 * * * 1000$ \\
\hline Participants $^{2}$ (ln, mean dev.) & $0.021 * * *$ & $0.013 * * *$ & -- & $0.019 * * *$ \\
\hline 1/ participants & -- & -- & $2.501 * * *$ & -- \\
\hline 1/ (ln participants) & - & $2.495 * * *$ & -- & $0.217 *$ \\
\hline $1 /(\ln \text { participants })^{2}$ & - & $-1.237 * * *$ & - & - \\
\hline Real wage index $(\ln )$ & {$[1]^{\mathrm{f}}$} & [1] & [1] & [1] \\
\hline Industry funds (NC) & $0.499 * * *$ & $0.482 * * *$ & $0.308 * * *$ & $0.490 * * *$ \\
\hline Company funds & $0.654 * * *$ & $0.648 * * *$ & $0.434 * * *$ & $0.648 * * *$ \\
\hline Professional group funds & $0.967 * * *$ & $0.959 * * *$ & $0.734 * * *$ & $0.961 * * *$ \\
\hline Other funds & $0.528 * * *$ & $0.521 * * *$ & $0.342 * * *$ & $0.522 * * *$ \\
\hline Pension plan: DC $v s$ DB & $-0.053 *$ & $-0.054 *$ & -0.016 & $-0.052 *$ \\
\hline Pensioners & $0.464 * * *$ & $0.444 * * *$ & $0.517 * * *$ & $0.465 * * *$ \\
\hline Inactive participants & $-0.417 * * *$ & $-0.422 * * *$ & $-0.465 * * *$ & $-0.420 * * *$ \\
\hline Assets per 1000 participants & $1.480 * * *$ & $1.424 * * *$ & $1.545 * * *$ & $1.466 * * *$ \\
\hline Report invest cost & $-0.337 * * *$ & $-0.337 * * *$ & $-0.327 * * *$ & $-0.336 * * *$ \\
\hline Outsourcing & $0.972 * * *$ & $0.968 * * *$ & $0.931 * * *$ & $0.97 * * *$ \\
\hline Reinsured & $0.001 * *$ & $0.001 * *$ & $0.001 *$ & $0.001 * *$ \\
\hline Time & $0.052 * * *$ & $0.051 * * *$ & $0.050 * * *$ & $0.051 * * *$ \\
\hline Intercept & $-12.517 * * *$ & $-13.272 * * *$ & $-12.445 * * *$ & $-12.601 * * *$ \\
\hline No. of observations & 12,521 & 12,521 & 12,521 & 12,521 \\
\hline F-statistic & $3149 * * *$ & $2775 * * *$ & $2970 * * *$ & 2957 \\
\hline $\mathrm{R}^{2}$, adjusted (\%) & 71.8 & 71.8 & 71.6 & 71.8 \\
\hline Akaike's IC & 38,341 & 38,331 & 38,443 & 38,341 \\
\hline Wald test ${ }^{\mathrm{a}}$ & $1045 * * *$ & $532 * * *$ & $1006 * * *$ & $704 * * *$ \\
\hline First derivatives $^{c}$ & $\begin{array}{l}0.716+ \\
2 * 0.021 *(\ln p- \\
\ln p)\end{array}$ & $\begin{array}{l}0.781+2 * 0.013 \\
(\ln p-\overline{\ln p})-2.495 / \\
(\ln p)^{2}+2 * 1.237 / \\
(\ln p)^{3}\end{array}$ & $0.748-2.502 / p$ & $\begin{array}{l}0.726+2 * 0.019 \\
(\ln p-\overline{\ln p})- \\
0.217 /(\ln p)^{2}\end{array}$ \\
\hline Optimal size (in participants) $^{\mathrm{d}}$ & 768,394 & $8,048,941$ & No optimum & 1.192 .868 \\
\hline Cost elasticity at mean ${ }^{\mathrm{e}}$ & 0.717 & 0.736 & 0.748 & 0.725 \\
\hline
\end{tabular}

Note: $* * *$ and $* * *$ mean significantly different from zero at, respectively, the $90 \%, 95 \%$ and $99 \%$ confidence level, while ${ }^{000}$ indicates that the Wald test on Constant Returns to Scale (see footnote a) is rejected at the $99 \%$ confidence level.

${ }^{a}$ The Wald test regards the Constant Returns to Scale hypothesis: the coefficient of the linear term ln(number of participants) is equal to 1 , and the coefficient(s) of the non-linear term(s) is (are) equal to $0 ;{ }^{b}$ With $p$ for 'number of participants'. See Section 5.1 for details; ${ }^{\mathrm{c}}$ See Eq. (5.4-5.6); ${ }^{\mathrm{d}}$ The optimal scale is calculated by setting the first derivative equal to one, see Section 5.1 for details; ${ }^{\mathrm{e}}$. With mean referring to the mean value of the output measure, the number of participants, see Section $5.1 ;{ }^{\mathrm{f}}$ Coefficient has been set at 1 (homogeneous price relation).

economies are almost twice as large for the very small pension funds (compared to the $28 \%$ mean), while they disappear entirely for large pension funds. The concavity is less pronounced than in Bikker and de Dreu (2009), where the coefficient of the squared term was twice as large at 0.04. Fig. 6.1 shows the plotted cost elasticity curve against pension fund size, which is a straight line in this semi$\log$ graph. It is remarkable how small the corresponding confidence band is (not included in Fig. 6.1 for the sake of clarity), reflecting the dominant impact of scale economies. The optimal size number of participants in a pension fund is 768 thousand participants, with a $95 \%$ confidence band as wide as 368-1939 thousand. In 2009, and later years, the Dutch pension sector had only six pension funds, which were larger than this optimal size and (hence) no longer operated under economies of scale (12 
pension funds have more than 368 thousand participants and 2 more than 1939 thousand). Of course, for the assessment of optimal size and (dis)economies of scale we have to take the criticisms against the TCF into account.

\section{Unrestricted Laurent cost function}

The unrestricted Laurent cost function (ULF) differs from the translog function by having two additional reciprocal output terms, which are able to adjust (or generalize) the U-shaped or parabolic average costs of the TCF. Column 2 in Table 6.1 shows that both reciprocal terms are significant at the $1 \%$ level (possibly due to multicollinearity, see below). Note that the concavity term (the squared output term) is still significant, so that some support remains for the U-shaped cost curve. But the cost elasticity curve becomes flatter for pension funds with more participants (see Fig. 6.1), implying a flatter right leg of the U-shaped average cost curve. At the same time, the cost elasticity at the mean is - at 0.736 - slightly higher than according to the TCF. The optimal scale is estimated at 8 million participants, which is much higher than the optimal scale according to the TCF (768,394 participants). This would imply that, according to the ULF, no pension fund in the Netherlands is larger than this optimal-size estimate.

Fig. 6.1. Cost elasticity and optimal scale in the administration costs model

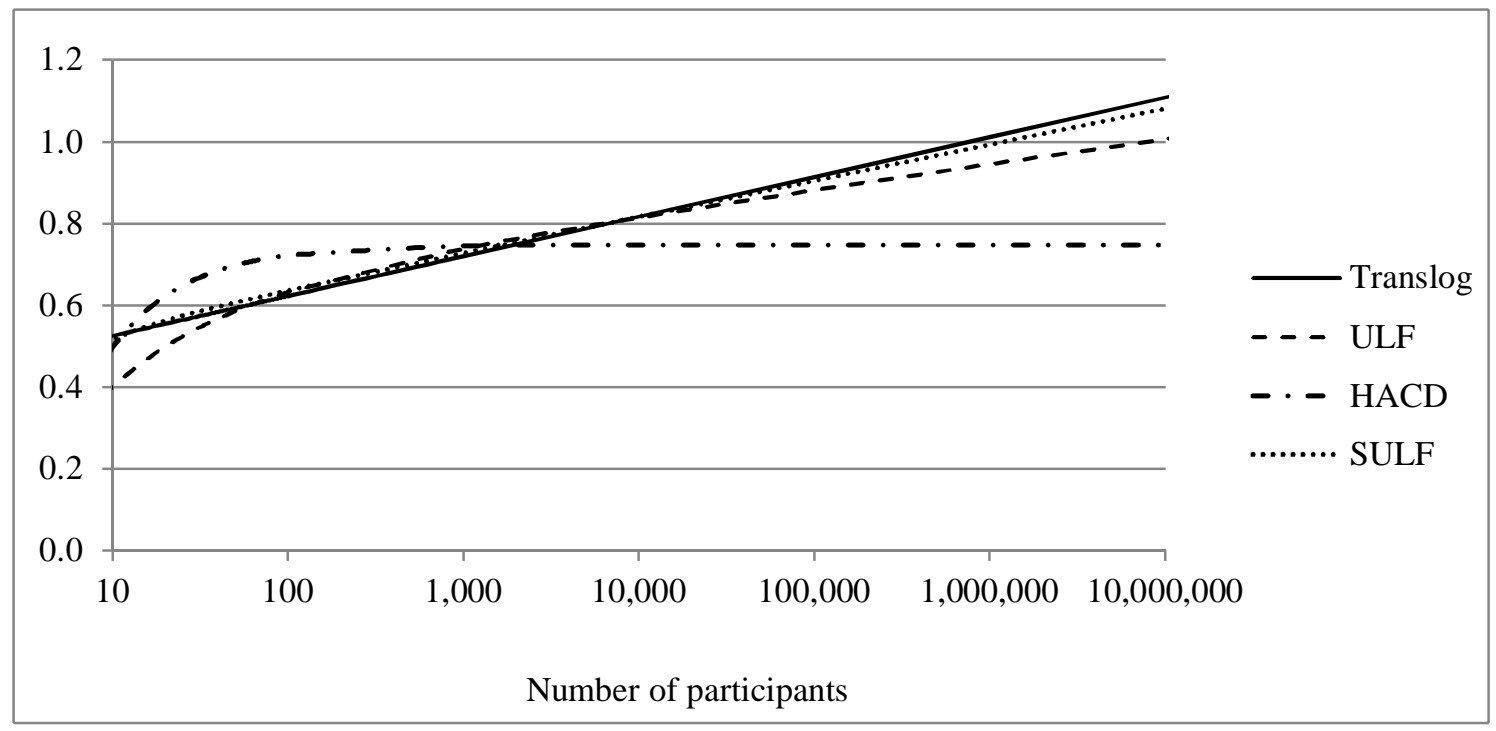

We apply the VIF test in order to check whether multicollinearity among the explanatory variables may be a problem. This test rejects the ULF, because of strong correlation $(0.93)$ between the two inverse output terms. Therefore we drop one of them. The last column in Table 6.1 shows the estimates for a simplified ULF, which hardly deviates from the TCF. The SULF optimum size is almost 1.2 million participants (with 95\% confidence band 488-4,273 thousand participants) instead of 768 thousand for the TCF. Note, however, that their confidence intervals overlap. 


\section{HACD model}

The third cost function considered is the hyperbolic HACD model, see Column 3 in Table 6.1. This model represents the monotonically decreasing (or non-increasing) average cost function. The cost elasticity is equal to 0.748 for pension funds with five thousand participants or more, and smaller for smaller pension funds, e.g. below 0.5 for ten participants (see Fig. 6.1). Hence, we find unused scale economies of $25.2 \%$ for larger funds and larger $S E$ for smaller funds.

To compare the estimated administrative cost models, we use the Akaike IC (AIC). The ULF reaches its lowest value at 38.331, but failed the VIF test. The simplified ULF (SULF) and the TCF have AIC values at an equally low level $(38,341)$, while the HACD's AIC, at 38,443, is 'significantly' higher, so that the HACD model appears to be less well-suited. Though the TCF and SULF models are highly similar in terms of goodness of fit (AIC and adjusted $\mathrm{R}^{2}$ ), their corresponding optimal sizes differ: 0.8 million versus 1.2 million participants. This result supports our approach of using various cost output models in order to reveal the underlying uncertainty about the true value of the optimal size. Moreover, it makes clear how sensitive the optimal size is for specification choices.

\section{Other determinants of administrative costs}

We now discuss the estimates of the other explanatory variables, stemming from the simplified ULF, which has an ex aequo low AIC. Note, however, that the estimated coefficients hardly vary across the four functional forms: none of the coefficients change sign and their magnitudes and significance levels hardly change. The real wage index and time are highly correlated (0.955) and do not pass the VIF test on multicollinearity, so that we cannot estimate both coefficients. In line with the standard hypothesis of price homogeneity, we set the coefficient of the wage index at 1 . Four pension fund type dummies reflect type-related variation in cost efficiency, where 'compulsory industry funds' - the category with the largest number of participants - acts as reference category. Hence, the dummy variables for non-compulsory (NC) industry funds, company funds, professional group funds and other funds measure the cost-level difference with compulsory industry funds. Apparently, all four governance types are significantly more expensive in both economic and statistical terms than compulsory industry funds (after controlling for other determinants), with NC industry funds having $63 \%$ higher costs $(63=\exp (0.490)-1)$, while company funds $(+91 \%)$ and professional group funds $(+161 \%)$ are even more expensive. Industry funds tend to offer relatively straightforward (standard) pension plans, leading to lower costs, while many company funds and professional group funds offer more tailor-made pension schemes, which may show up in higher costs (Bikker et al., 2012). Furthermore, industry funds may face fewer transfers of accrued pension rights, because employees often stay in the same industry if they switch jobs, resulting in little additional costs for the pension fund. The cost differences are smaller than in Bikker and de Dreu (2009) for 1992-2004. 
On average, DC pension plan tend to have lower costs than DB schemes, but the effect is not significant at the $5 \%$ level. With respect to participants we consider active and inactive participants and retirees. Pensioners imply 59\% higher costs, compared to active participants (the reference category), possibly due to the pay-out of pension benefits and increased communication. Inactive participants go with $52 \%$ lower costs, which is plausible as 'sleeping' pensions are less subject to changes and need less communication, et cetera. Costs increase significantly with assets per participant, arguably because administrative costs may go up (somewhat) with total assets. An alternative explanation is that pension funds with more wealthy participants - in terms of per capita total assets - increase luxury or face higher costs due to managerial complexity, see the introduction.

Some pension funds report zero investment costs, which is highly unlikely to be accurate. A part of them report net investment returns instead of gross ones, coupled with investment costs. Others may include (part of) their investment costs in the administrative costs. Our dummy variable 'pension funds reporting investment costs' tests the latter suspicion. The significantly negative coefficient leads to the conclusion that some pension funds do, in fact, include investment costs in administrative costs. The positive coefficient of outsourcing of administration shows that outsourcing indicates significantly higher costs. Logically, one would expect that outsourcing reduces costs, because specialized companies exploit their larger scale, offsetting their profit margin. In practice, particularly for company pension funds, the sponsor company bears part of the administrative costs, which will thus not show up in the bookkeeping of the pension fund. Outsourcing makes such costs visible, hence the positive coefficient.

Whether a pension fund is partly or fully reinsured does not affect administrative costs significantly at the 5\% level (except under the HACD model), but the economic impact is negligible. Costs increase over time, controlled for all other determinants, which may reflect an increase in accounting and supervisory requirements. The increase may also be caused by improved reporting of administrative cost over time. In any case, such effects dominate any cost-saving technical progress, e.g. in the area of IT and communication systems (Konings et al., 2002; Chatterton et al., 2010).

\subsection{Optimal scale estimates for individual years}

The regression results on the full dataset in Table 6.1 presents averages over 1992-2009. In order to obtain additional information about the developments over time, we re-estimate the cost models for each of the 18 years separately, and we do this for each of the three considered functional forms (Table 6.2). ${ }^{23}$ For the same reason as above, when solving the multicollinearity problem, we simplify

\footnotetext{
${ }^{23}$ Note that the real wage index and 'time' need to be dropped in the annual models.
} 
the ULF. Because the dummy and control variables are not especially relevant for the analysis on scale economies and optimal scale, they are neither reported in Table 6.2 nor discussed in the text.

Table 6.2. Scale economies and optimal scale of pension funds' administration by year

\begin{tabular}{|c|c|c|c|c|c|c|c|c|c|c|c|c|c|c|c|c|c|c|}
\hline & & & & & Transle & $g$ cost fu & nction & & Simplif & ed ULM & & & & & HACD & & & \\
\hline Year & $\begin{array}{r}\text { Geomet- } \\
\text { ric mean } \\
\text { of } \\
\text { particip } \\
\text { ant }\end{array}$ & $\begin{array}{l}\quad \# \\
O b- \\
\text { ser- } \\
\text { vat- } \\
\text { ions }\end{array}$ & $\begin{array}{r}\text { Costs } \\
\text { per } \\
\text { parti- } \\
\text { cipant } \\
(€)\end{array}$ & $\begin{array}{r}\text { Costs } \\
\text { per } \\
\text { parti- } \\
\text { cipant } \\
\text { (euro } \\
2000)\end{array}$ & $\begin{array}{l}\text { Cost } \\
\text { elas- } \\
\text { ticity }\end{array}$ & $\begin{array}{r}\text { Coeff. } \\
\text { of } \\
\text { squar } \\
\text { ed } \\
\text { term }^{a}\end{array}$ & $\begin{array}{r}\text { Optim } \\
\text { al size } \\
(x \\
1000)\end{array}$ & $\begin{array}{r}\text { Log- } \\
\text { like- } \\
\text { lihood }\end{array}$ & $\begin{array}{r}\text { Cost } \\
\text { elast- } \\
\text { icity }\end{array}$ & $\begin{array}{r}\text { Coef } \\
\text { ln- } \\
\text { partici } \\
\text { pants }\end{array}$ & $\begin{array}{r}\text { Coeff. } \\
\text { of } \\
\text { square } \\
\text { d term }^{a}\end{array}$ & $\begin{array}{r}\text { Coef. } \\
\text { of } \\
\text { reci- } \\
\text { procal }^{\text {prom }} \\
\text { term }^{a}\end{array}$ & $\begin{array}{r}\text { Optim } \\
\text { al size } \\
(x \\
1000)\end{array}$ & $\begin{array}{r}\log \\
\text { likeli- } \\
\text { hood }\end{array}$ & $\begin{array}{l}\text { Cost } \\
\text { elas- } \\
\text { ticity }\end{array}$ & $\begin{array}{r}\text { Coef } \\
\text { ln } \\
\text { par- } \\
\text { ticip- } \\
\text { ants }\end{array}$ & $\begin{array}{r}\text { Coef. } \\
\text { of } \\
\text { reci- } \\
\text { procal } \\
\text { term }\end{array}$ & $\begin{array}{r}\text { Log } \\
\text { like- } \\
\text { lihood }\end{array}$ \\
\hline 1992 & 469 & 759 & 25.5 & 30.5 & 0.65 & $0.04^{3}$ & 33 & $-1,239$ & 0.64 & 0.70 & $0.04^{3}$ & -0.31 & 44 & $-1,239$ & 0.71 & 0.71 & 3.27 & $-1,251$ \\
\hline 1993 & 478 & 792 & 26.0 & 30.4 & 0.67 & $0.04^{3}$ & 31 & $-1,288$ & 0.67 & 0.66 & $0.04^{3}$ & -0.13 & 29 & $-1,288$ & 0.73 & 0.73 & 3.53 & $-1,298$ \\
\hline 1994 & 513 & 788 & 29.5 & 33.6 & 0.67 & $0.04^{3}$ & 36 & $-1,263$ & 0.68 & 0.69 & $0.03^{3}$ & 0.32 & 45 & $-1,263$ & 0.74 & 0.74 & 3.78 & $-1,272$ \\
\hline 1995 & 534 & 789 & 30.4 & 33.8 & 0.69 & $0.04^{3}$ & 24 & $-1,265$ & 0.70 & 0.70 & $0.04^{3}$ & 0.23 & 27 & $-1,265$ & 0.76 & 0.76 & 3.88 & $-1,275$ \\
\hline 1996 & 590 & 786 & 34.6 & 37.8 & 0.70 & $0.04^{3}$ & 29 & $-1,261$ & 0.69 & 0.68 & $0.04^{3}$ & -0.45 & 24 & $-1,260$ & 0.75 & 0.75 & 2.62 & $-1,273$ \\
\hline 1997 & 639 & 776 & 34.8 & 37.2 & 0.76 & $0.03^{3}$ & 33 & $-1,216$ & 0.74 & 0.72 & $0.04^{3}$ & $-0.89^{1}$ & 21 & $-1,214$ & 0.79 & 0.79 & 1.32 & $-1,226$ \\
\hline 1998 & 679 & 784 & 44.3 & 46.4 & 0.73 & $0.03^{3}$ & 53 & $-1,253$ & 0.72 & 0.72 & $0.03^{3}$ & -0.34 & 43 & $-1,253$ & 0.77 & 0.77 & 2.28 & $-1,261$ \\
\hline 1999 & 781 & 754 & 43.0 & 44.1 & 0.74 & $0.03^{3}$ & 105 & $-1,164$ & 0.74 & 0.74 & $0.03^{3}$ & 0.01 & 106 & $-1,164$ & 0.77 & 0.77 & 2.43 & $-1,170$ \\
\hline 2000 & 898 & 768 & 46.0 & 46.0 & 0.73 & $0.02^{3}$ & 310 & $-1,159$ & 0.73 & 0.72 & $0.02^{3}$ & -0.2 & 230 & $-1,159$ & 0.76 & 0.76 & 2.07 & $-1,164$ \\
\hline 2001 & 1022 & 756 & 47.7 & 45.8 & 0.70 & $0.01^{1}$ & $>>^{b}$ & $-1,156$ & 0.69 & 0.67 & $0.02^{2}$ & -0.89 & 3,100 & $-1,155$ & 0.71 & 0.71 & 0.09 & $-1,158$ \\
\hline 2002 & 1188 & 719 & 49.6 & 46.1 & 0.71 & $0.01^{2}$ & $>$ & $-1,068$ & 0.71 & 0.71 & $0.02^{1}$ & -0.11 & $>>^{b}$ & $-1,068$ & 0.73 & 0.73 & 1.29 & $-1,070$ \\
\hline 2003 & 1339 & 694 & 51.5 & 46.9 & 0.73 & $0.01^{1}$ & $>>$ & -973 & 0.74 & 0.74 & 0.01 & 0.18 & $\gg$ & -973 & 0.75 & 0.75 & 1.66 & -974 \\
\hline 2004 & 1556 & 647 & 48.0 & 43.2 & 0.71 & 0.01 & $\gg$ & -865 & 0.72 & 0.74 & 0 & 0.62 & $>$ & -865 & 0.73 & 0.73 & 1.80 & -865 \\
\hline 2005 & 1669 & 643 & 52.9 & 46.8 & 0.76 & 0.00 & $>>$ & -889 & 0.77 & 0.78 & 0 & 0.63 & $\mathrm{NO}^{\mathrm{c}}$ & -889 & 0.77 & 0.77 & 1.07 & -889 \\
\hline 2006 & 1863 & 590 & 54.8 & 47.9 & 0.73 & 0.00 & $\gg$ & -813 & 0.75 & 0.76 & 0 & 0.76 & NO & -812 & 0.75 & 0.75 & 1.41 & -813 \\
\hline 2007 & 2186 & 542 & 52.9 & 45.5 & 0.68 & 0.00 & $>$ & -648 & 0.66 & 0.64 & 0.01 & -1.23 & NO & -648 & 0.67 & 0.67 & -0.43 & -649 \\
\hline 2008 & 2515 & 490 & 58.8 & 49.4 & 0.67 & 0.01 & $\gg$ & -606 & 0.67 & 0.67 & 0 & 0.2 & NO & -606 & 0.67 & 0.67 & 0.94 & -607 \\
\hline 2009 & 2981 & 444 & 62.1 & 51.5 & 0.66 & $0.01^{1}$ & $\gg$ & -538 & 0.68 & 0.69 & 0.01 & 0.94 & $\gg$ & -537 & 0.69 & 0.69 & 3.02 & -538 \\
\hline Avgs & 936 & & & & 0.71 & & & & 0.71 & & & & & & 0.74 & & & \\
\hline Sum & 12,521 & & & & & & & $-18,665$ & & & & & & $-18,657$ & & & & $-18,752$ \\
\hline
\end{tabular}

Note: Euro 2000 stands for: in prices of 2000. 'Super indices 1,2 and 3 in the column 'Coefficient of squared term' under Translog cost model indicate significance levels of, respectively, $10 \%, 5 \%$ and $1 \% ;^{\mathrm{b}}$ ' $>>$ ' means larger than 10 million participants; ${ }^{\mathrm{C} O}$ means: no optimum exists.

During the years 1992-1997 the optimal pension fund size according to the translog cost function varied between 24,000 and 36,000 participants, implying that larger pension funds (representing 3\% of the respective samples) faced diseconomies of scale and were less efficient than smaller pension funds. For the simplified ULF, these ranges are between 21 and 45 thousand participants. For the HACD model Table 6.2 shows scale economies only, because this model does not indicate an optimal scale. Because the optimal scale estimate depends on the observations of the largest pension funds, we re-estimated our model with weighted least squares (where the weight is the square root of the number of participants), in order to attach more weight to the largest observations, see Appendix. Fig. 6.2 shows that the optimal scale over 1992-1998 is estimated at 50-100 thousand participants, rising to 1 million in 2002-2003 and up to 5-10 million in the last years. The 95\% confidence band is wide, but the upward trend is clear cut. This implies that, in 2009, each pension fund would save cost after growing or merging. The outcome reflects that over time fixed costs have increased more than proportionally. Additional supervisory and other regulation and information technology have contributed to that. 
Fig. 6.2. Optimal scale in the 'weighted' administrative cost model over time with confidence bands

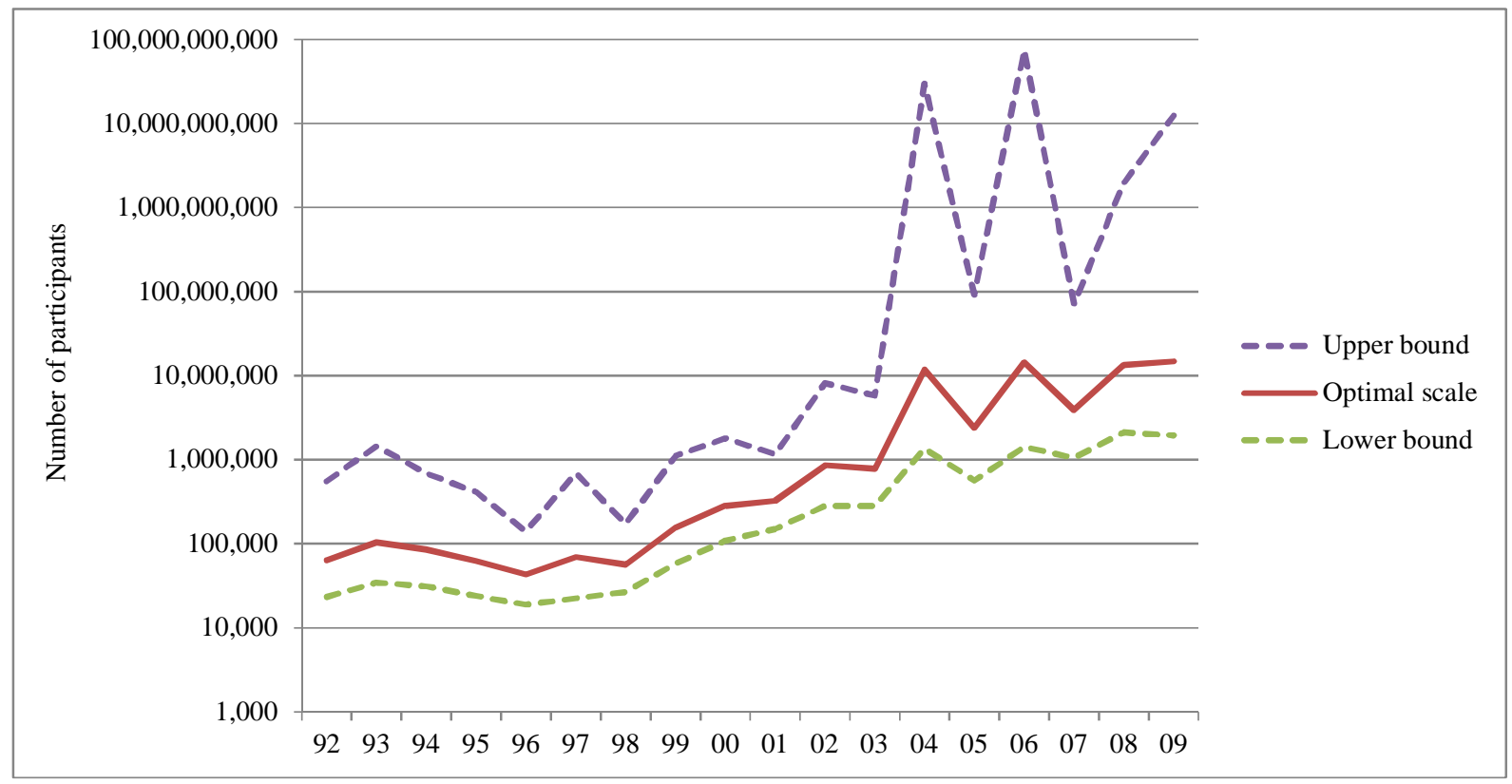

The estimated cost elasticities for the mean pension fund size show a similar pattern for all considered cost functions: fluctuation somewhat around 0.71 (TCF and ULF) or around 0.74 (HACD), rising somewhat to a higher level during 1997-2005, and sliding back in recent years. This implies that the average scale economies at the geometric mean did not fundamentally shifted over time, where that mean of course shifts from almost 500 participants in 1992 to 3000 participants in 2009. This implies that the functional forms of the TCF and the ULF in Fig. 6.1 (and the underlying unit cost function) shift over time to the right, so that the optimal scale increases. Without consolidation of the pension sector, the unused scale economies would not have remained constant, but would have increased.

\section{Empirical results for the investment cost model}

This section focuses on investment costs, which consist of portfolio management, financial research, trading facilities and advice costs. Transaction fees, brokerage fees and management fees of mutual funds are not included, as they are normally already deducted from the investment returns. As for the administrative costs investigation, a number of different costs functions will be used to estimate the scale economies. The translog function for investment costs reads as:

$\ln I C_{i t}=\alpha+\beta_{1}\left(\ln {\text { total } \text { assets }_{i t}}\right)+\beta_{2}\left(\ln {\text { total } \text { assets }_{i t}}-\overline{\ln \text { total assets }}\right)^{2}+\gamma_{1} \ln$ real wage $_{t}+$ $\gamma_{2}$ governance dummies $_{i t}+\gamma_{3}$ pension plan design $_{i t}+\gamma_{4}$ type of participants $_{i t}+\gamma_{5}$ assets per participants $_{i t}+\gamma_{6}$ reinsurance $_{i t}+\gamma_{7}$ asset allocation $+\gamma_{8}$ time $_{t}+\varepsilon_{i t}$ 
The Unrestricted Laurent model is based on Eq. (7.1) extended by $\beta_{3}(1 / \ln$ total assets $)+\beta_{4}(1 /$ (ln total assets $)^{2}$ ), while the HACD cost model is equal to Eq. (7.1) where the $2^{\text {nd }}$ term has been replaced by $\beta_{2}$ (1/ total assets). Unlike in Eq. (5.7) for administrative costs, we here use 'total assets' as output measure instead of 'number of participants'. Furthermore, we delete 'outsourcing of administration' and 'reporting of investment costs' as explanatory variables and we add 'assets allocation'. Assets allocation consists of the shares of the following asset categories: stocks, real estate, private equity, commodities, hedge funds and other assets, all as percentage of total investments. The share of bonds acts as the reference category. The coefficients of these variables represent by approximation the risk management costs of the respective investment category, compared to that of bonds. Riskier investments cause higher investment costs due to more research, complicated transactions and extra risk management, while also having higher expected returns (Bauer et al., 2010).

\subsection{Empirical results for 1992-2009}

This section displays the results of the three different cost functions for the entire data sample consisting of 7109 annual non-zero observations of pension funds, while the next section presents results for each of the 18 years separately. The upper panel of Table 7.1 shows the regression results for the three cost functions, while the lower panel displays a possible optimal scale and the cost elasticities at the mean values for investment costs. The first derivative is used to calculate those factors.

\section{Translog cost function}

The investment cost elasticity at the (geometric) mean - of $€ 80$ million - is 0.88 . The Wald test rejects the constant returns to scale hypothesis (cost elasticity is 1 , quadratic effect is 0 ) at the $1 \%$ significance. Hence, scale economies are important in the investment activities too (at 12\%), but much less so than in administrative activities (28\%), and also less than during 1992-2004 (22\%), see Bikker and de Dreu (2009). Apparently, fixed cost - the origin of scale economies - occur less in investment than in administration. As the squared output term coefficient is significantly different from 0 , there is evidence of a concave relationship between investment costs and output size (total assets), implying that small pension funds face higher scale economies and large funds experience lower scale economies. Fig. 7.1 shows the plotted cost elasticity curve against pension fund size, which is a straight rising line in this semi-log graph. An optimal fund size occurs at total assets of $€ 690$ million, with confidence interval $€ 567-813$ million. In 2009 , the Dutch pension sector numbers no fewer than 83 pension funds with total assets above $€ 690$ million.

We have observed that some pension funds underreport administrative cost, particularly smaller funds. Note that that implies that actual scale economies are likely higher that what we have found, as full reporting would have raised the cost of smaller pension funds further. 


\section{Unrestricted Laurent function}

The two additional reciprocal terms of the unrestricted Laurent cost function are highly correlated (at 0.988) and do not pass the VIF test on multicollinearity. Our solution is to simplify the model by

Table 7.1. Estimates of the investment cost model (1992-2009)

\begin{tabular}{|c|c|c|c|c|}
\hline Variable & Translog & $\begin{array}{l}\text { Unrestricted } \\
\text { Laurent function }\end{array}$ & Simplified ULF & HACD \\
\hline Ta (in logarithms) & $0.880^{* * * *} j^{\text {poo a }}$ & $1.515^{* * * * p^{000}}$ & $1.380 * * * p^{000}$ & $0.938 * * * p^{000}$ \\
\hline $\mathrm{Ta}^{2}$ (in ln, mean dev.) & $0.028 * * *$ & -0.021 & $-0.015^{* *}$ & - \\
\hline $1 / \mathrm{ta}$ & -- & -- & -- & $655 * * *$ \\
\hline $1 /(\ln$ ta) & - & 87.186 & $57.068 * * *$ & -- \\
\hline $1 /(\ln \mathrm{ta})^{2}$ & -- & -73.901 & -- & - \\
\hline Real wage index $(\ln )$ & {$[1]^{\mathrm{f}}$} & [1] & [1] & [1] \\
\hline Industry fund (NC) & 0.095 & 0.091 & 0.093 & 0.088 \\
\hline Company fund & $0.287 * * *$ & $0.290 * * *$ & $0.290 * * *$ & $0.242 * * *$ \\
\hline Prof. group fund & $0.534 * * *$ & $0.514 * * *$ & $0.515 * * *$ & $0.481 * * *$ \\
\hline Other funds & $0.349 * * *$ & $0.344 * * *$ & $0.345 * * *$ & $0.338 * * *$ \\
\hline Pension plan (DB/DC) & 0.024 & 0.006 & 0.006 & 0.018 \\
\hline Stocks & $0.583 * * *$ & $0.558 * * *$ & $0.559 * * *$ & $0.555^{* * *}$ \\
\hline Real estate & $1.489 * * *$ & $1.358 * * *$ & $1.362 * * *$ & $1.497 * * *$ \\
\hline Private equity & 0.129 & 0.237 & 0.237 & 0.330 \\
\hline Commodities & -2.995 & -3.420 & $-3.471 *$ & -3.052 \\
\hline Hedge funds & 0.954 & 1.020 & 1.023 & 1.284 \\
\hline Other funds & $-0.302 * *$ & $-0.274 * *$ & $-0.274 * *$ & $-0.255^{*}$ \\
\hline Pensioners & -0.050 & -0.088 & -0.087 & -0.073 \\
\hline Inactive participants & $0.274 * * *$ & $0.288 * * *$ & $0.289 * * *$ & $0.225 * *$ \\
\hline Reinsured & $-0.006^{* * *}$ & $-0.006^{* * *}$ & $-0.006^{* * *}$ & $-0.006 * * *$ \\
\hline Assets per 1000 partic. & $0.090 *$ & 0.087 & $0.089 *$ & $0.145 * *$ \\
\hline Time & $0.021 * * *$ & $0.020 * * *$ & $0.020 * * *$ & $0.019 * * *$ \\
\hline Intercept & $-17.420 * * *$ & $-31.717 * * *$ & $-28.103 * * *$ & $-17.936 * * *$ \\
\hline No. of obs. & 7109 & 7109 & 7109 & 7109 \\
\hline F-statistic & $1678 * * *$ & $1694 * * *$ & $1752 * * *$ & $1761 * * *$ \\
\hline $\mathrm{R}^{2}$, adjusted & 75.6 & 75.7 & 75.7 & 75.6 \\
\hline Akaike's IC & 20,990 & 20,936 & 20,938 & 20,993 \\
\hline Wald test ${ }^{a}$ & $178 * * *$ & $116^{* * *}$ & $161 * * *$ & $110 * * *$ \\
\hline First derivative ${ }^{b}$ & $0.880+2 * 0.028(\ln t)$ & $\begin{array}{l}1.515+2 * 0.021(\ln t) \\
-87.186 /(\ln t)^{2}+ \\
2 * 73.901 /(\ln t)^{3}\end{array}$ & $\begin{array}{l}0.84+2 * 0.026(\ln t) \\
-57.068 /(\ln t)^{2}\end{array}$ & $0.938-655 / t$ \\
\hline Optimal scale (assets) ${ }^{\mathrm{c}}$ & 690 million & 565 million & 690 million & No optimal point ${ }^{\mathrm{d}}$ \\
\hline Cost elasticity at mean & 0.880 & 0.935 & 0.933 & 0.930 \\
\hline
\end{tabular}

Note: $* * *$ and $* * *$ mean significantly different from zero at, respectively, the $90 \%, 95 \%$ and $99 \%$ confidence level, while ${ }^{\circ o 0}$ indicates that the Wald test (see footnote a below) is rejected at the $99 \%$ confidence level.

${ }^{a}$ The Wald test regards the Constant Returns to Scale hypothesis: the coefficient of the linear term $\ln$ (total assets) is equal to 1 , and the coefficients of the non-linear terms are equal to $0 ;{ }^{b}$ With $t$ for 'total assets'. See Section 5.1 for details; ${ }^{\mathrm{c}}$ The optimal scale is calculated by setting the first derivative equal to one, see the method section for details; ${ }^{\mathrm{d}}$ According to the HACD model, an optimal scale does not exist; ${ }^{\mathrm{e}}$ With mean referring to the mean value of the output measure, total assets, see Section 5.1; ${ }^{\mathrm{f}}$ Coefficient has been set at 1 (homogeneous price relation).

deleting the second reciprocal term (see column 'simplified ULF'). The average scale economies are only 7\%. Fig.7.1 shows that the reciprocal term of the SULF causes additional curvature, confirming the large unused scale economies of pension funds with small portfolios as found by the TCF, but rejecting diseconomies of scale for large pension funds (as does the TCF). The cost elasticity curve 
just crosses the constant-return-to-scale (CRS) axis $(\mathrm{y}=1)$ at exactly the same point as the TCF ( 690 million) and later bends back. This outcome suggest that all portfolio sizes above $€ 690$ million are optimal, which make sense from an economic view. Apparently, the average cost curve falls gradually for smaller funds but remains flat after the minimum average cost level has been reached. The cost elasticity at the geometric mean ( $€ 80$ million) is at 0.93 higher than in the TCF $(0.88)$, but still significant different from CRS. Hence, the average scale economies (SE) according to the SULF model are $7 \%$ instead of $12 \%$ (according to the TCF). Of course, the $S E$ are larger for smaller funds and virtually zero for larger funds.

\section{Fig. 7.1. Cost elasticity and optimal scale in the investment costs model}

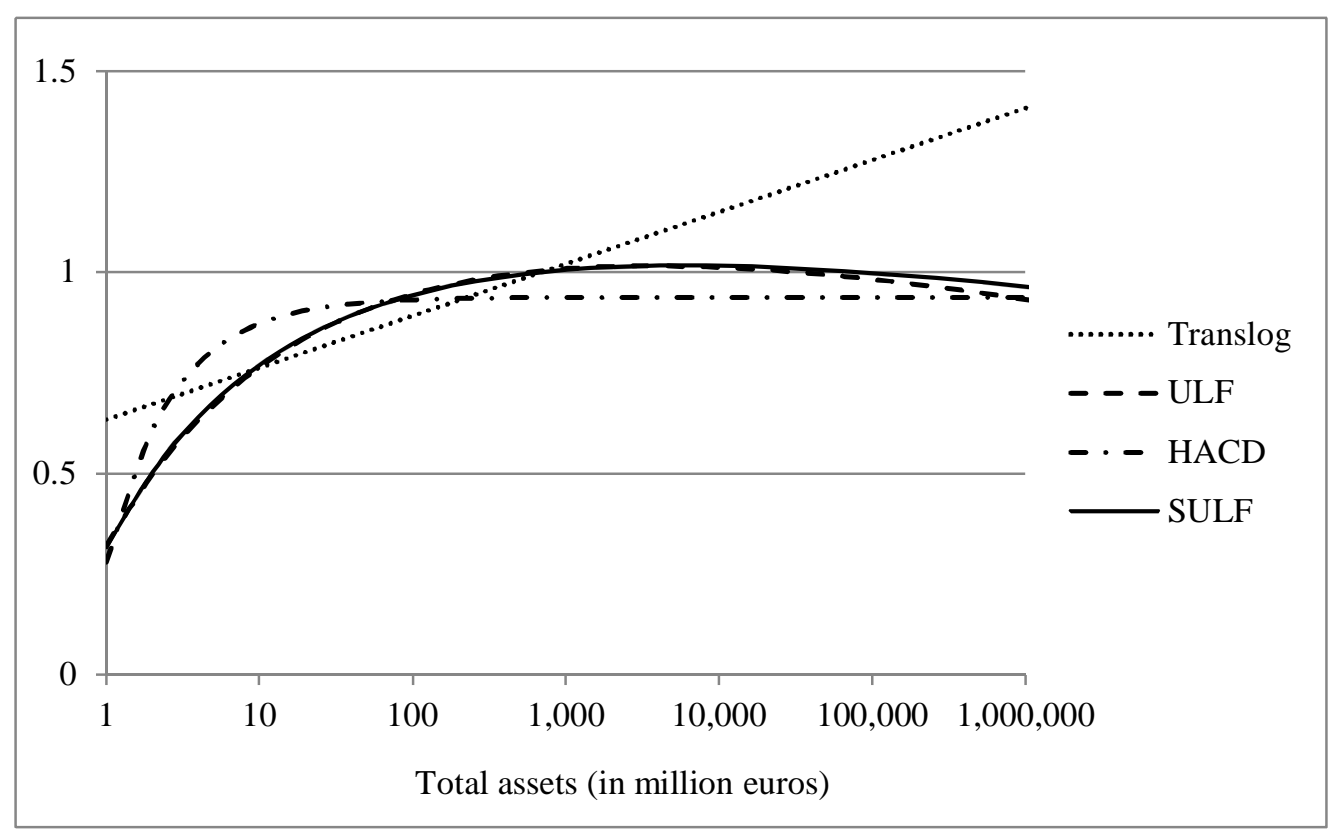

\section{HACD cost function}

The third cost function considered is the hyperbolic HACD model, see Column 3 in Table 7.1. This model represents the monotonically decreasing average cost function, where an optimal scale, or better, diseconomies of scale, may be absent. The cost elasticity increases to 0.930 at the geometric mean, and up to 0.938 for larger pension funds, again significantly different from CRS, see Fig. 7.1. An optimal scale is absent: unused scale economies of $6.2 \%$ continue to exist for pension funds of any size. Of course, the flexibility of the HACD model is limited.

To compare the estimated investment cost models, we again use the Akaike IC (AIC). Where the TCF and SULF models for administrative costs have a similar AIC value, the (S)ULF for investment cost outperforms the TCF (and HACD) fiercely. Hence, the conclusion is that for investments, scale economies do exist, but decline for larger funds with total assets up to (around) $€ 690$ million and are absent for larger funds. 


\section{Other determinants of investment costs}

We will now discuss the estimates of the other explanatory variables stemming from the SULF. Note, however, that the estimated coefficients hardly vary across the four functional forms: none of the coefficients change sign and their magnitude and significance levels hardly change. As observed above, the real wage index and time are highly correlated. In line with the standard hypothesis of price homogeneity, also here we set the coefficient of the wage index at 1 . Three governance types are, in both economic and statistical terms, significantly more expensive than compulsory industry funds (after controlling for other determinants), as has been the case for administrative costs too: company funds having $34 \%$ higher investment costs, while other funds (42\%) and professional group funds $(67 \%)$ are even more expensive, roughly in line with Bikker and de Dreu (2009). A convincing explanation is lacking. Bauer et al. (2010) and Chatterton et al. (2010) expect lower costs for DB plans, as they make more frequent use of asset-liability matching strategies and invest more in fixedincome assets that generally entail lower costs. However, we do not find any difference between DC and DB schemes. Note that the asset allocation variables take any different investment strategies into account.

Fig. 4.6 shows that large funds hold more complex assets with correspondingly higher risk management costs, while on the other hand, larger pension funds benefit from lower unused scale economies. Therefore we need to disentangle these two size effects. This can be done by including pension fund-specific asset allocation variables for the first size effect and output for the second size effect. The asset allocation variables do, in fact, indicate significantly higher investment research and risk management costs for the riskier assets. This is most evident for stocks (75\% more expensive than bonds) and real estate (290\%). It may also hold for private equity and hedge funds, but their coefficients are not statistically significant. Other assets, including money market funds, are significantly less costly than bonds, all in line with expectations. The coefficient of commodities is not significant.

With respect to type of participants, we observe higher investment costs for inactive participants, but a clear explanation is lacking. Reinsurance, i.e. full or partial outsourcing of liability and investment risks, reduces investment costs significantly, as expected, but the economic impact is low. Costs increase over time, controlled for all other determinants, which may in part reflect improved reporting of investment costs over time. Of course, investment techniques, research, risk management, technical progress, and reporting requirements have all significantly changed over time. 


\subsection{Optimal scale estimates for individual years}

The regression results on the full dataset in Table 7.1 presents averages over 1992-2009. In order to obtain additional information about the developments over time, we re-estimate each of the three considered investment cost models for each of the 18 years separately (Table 7.2). ${ }^{24}$ For the same reason as above, when addressing the multicollinearity problem, we simplify the ULF. Because the dummy and control variables are not especially relevant for the analysis on scale economies and optimal scale, they will not be reported in Table 7.2 nor discussed in the text.

Table 7.2 Scale economies and optimal scale of pension fund investments by year

\begin{tabular}{|c|c|c|c|c|c|c|c|c|c|c|c|c|c|c|c|c|c|c|}
\hline \multirow[b]{2}{*}{ Year } & \multirow[b]{2}{*}{$\begin{array}{r}\text { Geom- } \\
\text { etric } \\
\text { mean } \\
\text { of } T A \\
\text { (mil- } \\
\text { lions) } \\
\end{array}$} & \multicolumn{6}{|c|}{ Translog } & \multicolumn{4}{|c|}{ Simplified ULF } & \multicolumn{7}{|c|}{ HACD } \\
\hline & & $\begin{array}{l}\text { \# } \\
\text { Ob- } \\
\text { ser- } \\
\text { vat- } \\
\text { ions }\end{array}$ & $\begin{array}{r}\text { Cost } \\
\text { per } \\
\text { mln } \\
\text { euro } \\
\text { of } \\
\text { TA } \\
\end{array}$ & $\begin{array}{r}\text { Ditto } \\
\text { in } \\
\text { euro } \\
2000\end{array}$ & $\begin{array}{r}\text { Cost } \\
\text { elast- } \\
\text { icity }\end{array}$ & $\begin{array}{l}\text { Coeff. } \\
\text { of } \\
\text { sqrd. } \\
\text { term }^{a}\end{array}$ & $\begin{array}{r}\text { Opti- } \\
\text { mal } \\
\text { size }(x \\
\text { mil- } \\
\text { lion } \\
\text { euros })\end{array}$ & $\begin{array}{l}\text { Log- } \\
\text { likeli- } \\
\text { hood }\end{array}$ & $\begin{array}{l}\text { Cost } \\
\text { elas- } \\
\text { ticity }\end{array}$ & $\begin{array}{r}\text { Coef } \\
\text { ln } \\
T A\end{array}$ & $\begin{array}{r}\text { Coeff. } \\
\text { of } \\
\text { sqrd. } \\
\text { term }\end{array}$ & $\begin{array}{r}\text { Coeff. } \\
\text { of } \\
\text { reci- } \\
\text { proc- } \\
\text { al } \\
\text { term }\end{array}$ & $\begin{array}{r}\text { Opti- } \\
\text { mal } \\
\text { size }(x \\
\text { mil- } \\
\text { lion })\end{array}$ & $\begin{array}{c}\text { Log } \\
\text { likeli } \\
\text { hood }\end{array}$ & $\begin{array}{l}\text { Cost } \\
\text { elast } \\
\text {-icity }\end{array}$ & $\begin{array}{r}\text { Coeff } \\
. \ln \\
T A\end{array}$ & $\begin{array}{r}\text { Coeff. } \\
\text { of } \\
\text { reci- } \\
\text { pro- } \\
\text { cal } \\
\text { term }\end{array}$ & $\begin{array}{c}\text { Log } \\
\text { likeli } \\
\text { hood }\end{array}$ \\
\hline 1992 & 41 & 231 & 940 & 1126 & 0.78 & $0.04^{3}$ & 649 & -325 & 0.79 & 0.92 & 0.03 & 14 & 699 & -325 & 0.87 & 0.87 & 661 & -328 \\
\hline 1993 & 36 & 272 & 893 & 1042 & 0.79 & $0.02^{1}$ & 2,636 & -377 & 0.81 & 0.99 & 0.01 & 20 & 10,245 & -377 & 0.86 & 0.86 & 584 & -377 \\
\hline 1994 & 34 & 300 & 713 & 811 & 0.74 & $0.05^{3}$ & 519 & -444 & 0.78 & 1.06 & 0.02 & 31 & 672 & -444 & 0.83 & 0.83 & 511 & -448 \\
\hline 1995 & 37 & 317 & 687 & 765 & 0.76 & $0.03^{3}$ & 1,757 & -456 & 0.77 & 0.81 & 0.03 & 5 & 1,980 & -456 & 0.84 & 0.84 & 552 & -457 \\
\hline 1996 & 45 & 337 & 467 & 510 & 0.76 & $0.03^{3}$ & 1,955 & -484 & 0.79 & 1.06 & 0.01 & 31 & 4,009 & -483 & 0.85 & 0.85 & 809 & -485 \\
\hline 1997 & 52 & 359 & 461 & 493 & 0.81 & $0.03^{3}$ & 1,187 & -523 & 0.85 & 1.16 & 0.00 & 36 & 4,824 & -522 & 0.87 & 0.87 & 297 & -524 \\
\hline 1998 & 66 & 408 & 433 & 454 & 0.83 & $0.02^{1}$ & 5,780 & -571 & 0.91 & 1.50 & -0.04 & 72 & $\mathrm{NO}^{\mathrm{b}}$ & -567 & 0.89 & 0.90 & 598 & -567 \\
\hline 1999 & 78 & 410 & 478 & 491 & 0.88 & 0.01 & 45,703 & -575 & 0.90 & 1.06 & -0.01 & 21 & $\mathrm{NO}$ & -575 & 0.90 & 0.90 & 385 & -575 \\
\hline 2000 & 87 & 447 & 640 & 640 & 0.88 & 0.02 & 2,529 & -620 & 0.89 & 0.98 & 0.01 & 12 & 3,557 & -620 & 0.91 & 0.91 & 517 & -621 \\
\hline 2001 & 82 & 477 & 668 & 641 & 0.89 & 0.01 & 5,983 & -663 & 0.92 & 1.27 & -0.02 & 44 & NO & -662 & 0.93 & 0.93 & 678 & -662 \\
\hline 2002 & 83 & 462 & 848 & 788 & 0.89 & 0.01 & 23,925 & -611 & 0.91 & 1.15 & -0.01 & 31 & NO & -610 & 0.92 & 0.92 & 605 & -610 \\
\hline 2003 & 87 & 482 & 989 & 900 & 0.92 & $0.02^{2}$ & 622 & -674 & 0.94 & 1.14 & 0.00 & 25 & 572 & -673 & 0.96 & 0.96 & 593 & -674 \\
\hline 2004 & 94 & 484 & 1019 & 917 & 0.91 & $0.03^{3}$ & 328 & -736 & 0.93 & 1.11 & 0.02 & 24 & 275 & -736 & 0.97 & 0.97 & 728 & -739 \\
\hline 2005 & 109 & 505 & 1248 & 1103 & 0.94 & $0.02^{1}$ & 553 & -740 & 1.00 & 1.58 & -0.03 & 78 & 95 & -738 & 1.00 & 1.00 & 943 & -739 \\
\hline 2006 & 128 & 474 & 1140 & 997 & 0.94 & $0.02^{1}$ & 420 & -753 & 1.02 & 1.75 & -0.04 & 101 & 79 & -750 & 1.02 & 1.02 & 1309 & -750 \\
\hline 2007 & 146 & 423 & 2097 & 1805 & 0.93 & $0.02^{1}$ & 607 & -632 & 1.00 & 1.54 & -0.03 & 76 & 152 & -630 & 0.99 & 0.99 & 892 & -629 \\
\hline 2008 & 157 & 379 & 2550 & 2141 & 1.00 & $0.02^{2}$ & 171 & -551 & 1.05 & 1.56 & -0.03 & 72 & 42 & -550 & 1.04 & 1.04 & 766 & -550 \\
\hline 2009 & 202 & 342 & 1978 & 1642 & 0.97 & $0.02^{2}$ & 418 & -464 & 1.02 & 1.50 & -0.03 & 71 & 97 & -462 & 1.01 & 1.01 & 967 & -462 \\
\hline$\overline{\text { Avgs }}$ & 80 & & & & 0.87 & & & & 0.90 & & & & & & 0.93 & & & \\
\hline Sum & & 7,109 & & & & & & 10,199 & & & & & & $-10,181$ & & & & 0,196 \\
\hline
\end{tabular}

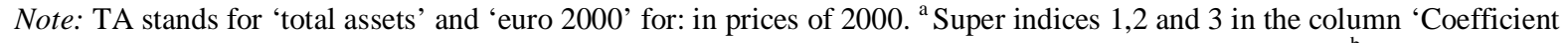
of squared term' under Translog cost model indicate significance levels of, respectively, $10 \%, 5 \%$ and $1 \%$. ${ }^{\mathrm{b}}$ NO means: no optimum exists.

The most remarkable outcome is that the cost elasticity at the (geometric) mean increased over time by around 0.20. Comparing the first and the last five years, the cost elasticity shifted in the TCF from 0.75 to 0.95 , in the SULF from 0.80 to 1 and in the HACD from 0.85 to around 1 . This means that scale economies for the average pension fund were large in the earlier years, but declined or vanished in the later years. This contrasts with the administrative costs, where we observe elasticities and scale economies for the average fund, which are constant over time. We further observe that the coefficient of the squared output term in the TCF remains above 0.01 over the entire sample period, implying that

\footnotetext{
${ }^{24}$ Note that the real wage index and 'time' need to be dropped in the annual models.
} 
scale economies decline with pension fund size..$^{25}$ This, too, contrasts with the administrative costs, where the coefficient of the squared output term ebbed to below 0.002 , that is virtually zero, so that scale economies became equal for each size class.

Fig. 7.2 shows the ULF cost curve for three separate years, which represent the trend over time. These curves show that large unused scale economies remain present for small pension funds. For the larger funds, however, the trend indicates a change from diseconomies of scale, via constant returns to scale, towards residual or even increasing scale economies. A remarkable phenomenon shown in Fig. 7.2 is that the flexible ULF mimics the TCF for 1992 and following years, with a clear optimal scale and scale diseconomies for larger funds, while for 1999 and other years in that area, it represents the HACD model with average investment costs declining monotonically and flat cost elasticity, so that scale economies exist for all medium-sized and large pension funds and the level of scale economies is constant. For 2008 and other recent years, the curve bends further, reflecting monotonically declining average costs, which describes a more complicated cost or production structure: medium-sized pension funds are unable to exploit unused scale economies (as long as they expand by small steps only), while larger pension funds are able to do so. This outcome also illustrates the shortcomings of

Fig.7.2. Cost elasticity and optimal scale in the simplified ULF of investment costs

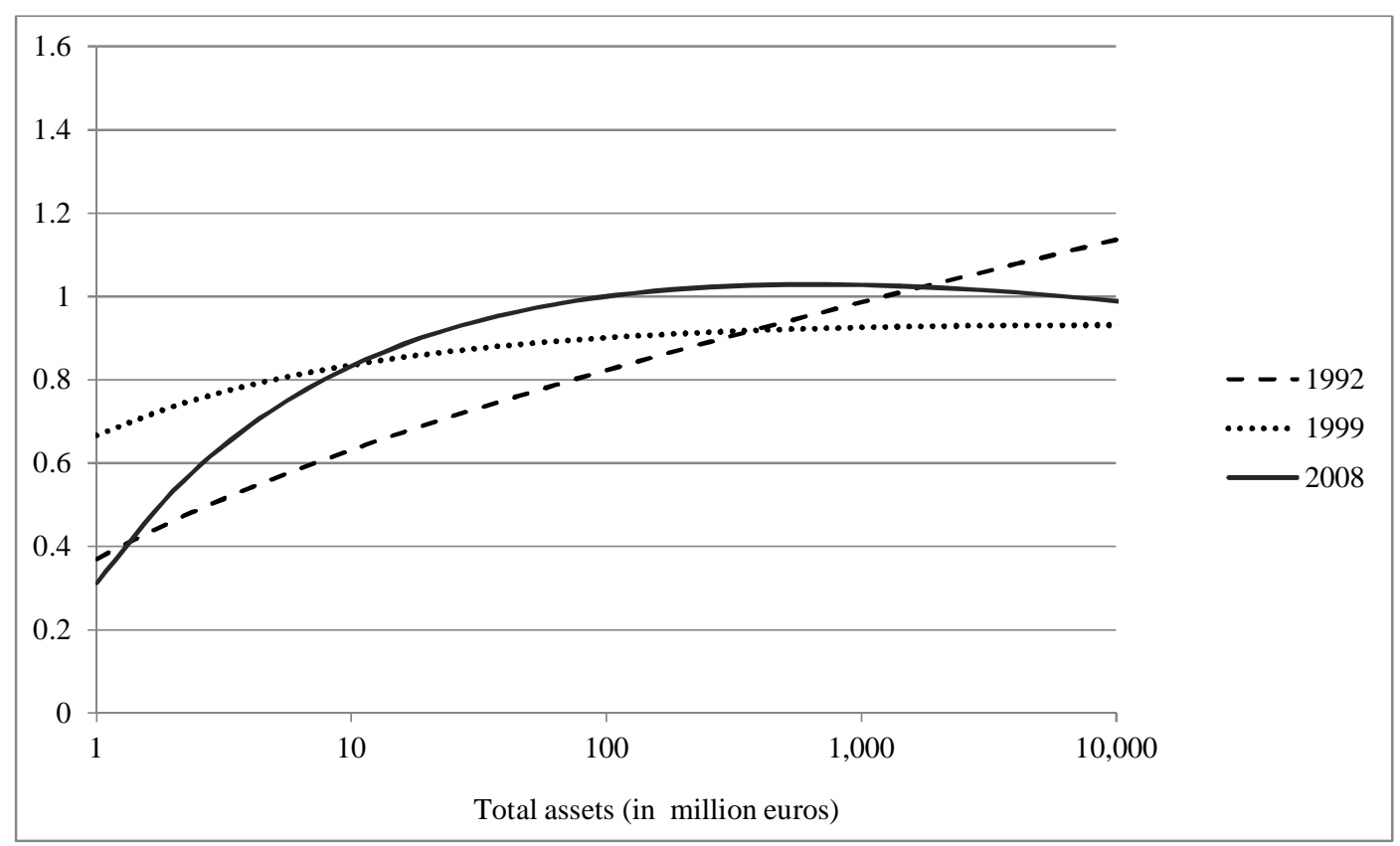

the TCF, which can produce straight lines only (in this semi log graph), and of the HACD model, which invariably ends in a horizontal line.

\footnotetext{
${ }^{25}$ Though not significantly different from zero during 1998-2002 and in some of the later years, see Table 7.2. For the administrative cost model, the significance ended completely after 2002, see Table 6.2.
} 
Table 7.2 shows that the optimal size estimate fluctuates heavily over time, indicating lack of robustness. Given that the TCF may be misleading with respect to optimal scale estimates, we focus on the simplified ULF cost. For most years, the SULF elasticity curve touches the $y=1$ or CRS axis, but Fig. 7.2 explains that the optimal scale figures may indicate the start of a (possibly ending) optimal scale range. If the curve does not touch the CRS axis, we find 'no optimum' and hence scale economies for all sizes. We conclude that in recent years an optimal scale for investment cost does not exist but that pension funds beyond a certain scale operate under conditions close to CRS.

\section{Summary and conclusions}

This paper investigates the methodological problem of scale economy measurement and demonstrates the sensitivity of the cost model's functional form, particularly with respect to determining optimal scale. An underlying question is whether the average costs form a $U$ shape, which implies existence of an optimal scale, or whether they decline monotonically, so that scale economies continue to exist at any scale. Exploring three different functional forms, we find that the often-used translog cost function has the drawback of assuming an underlying U-shaped average cost function, as soon as the costoutput relationship becomes non-linear. The hyperbolically-adjusted Cobb Douglas model is also too limited, as it assumes a monotonically decreasing average cost function throughout. The unrestricted Laurent function (ULF) is more general and able to describe both types of underlying average cost functions. While the scale economy estimates for the mean pension funds are quite similar across the three functional forms, the conclusions with respect to an optimal scale diverge widely.

Turning to the empirical results for the superior ULF, the administrative costs model shows that for the average pension fund in the Netherlands significant scale economies (SE) exist of about $27 \%$. These SE are size dependent: up to 50\% and more for small pension funds, but lower or even zero for larger funds. Over time, using annual estimates, the SE remain fairly constant. An optimal scale over the entire sample period is estimated at somewhat above 1 million participants, but it is much lower over 1992-1999 and increases during subsequent years to a scale above that of the largest Dutch pension fund. This suggests that average administrative costs per participant now decline without limit.

For investment costs, the picture is different. First, the SE are small at $7 \%$ for the average pension fund. The SE are larger for smaller funds and declining to zero for larger funds. The optimal scale is reached around a portfolio size of $€ 690$ million, while larger funds remain equally cost efficient. If we focus on annual estimates, we find that the optimal scale does not shift over time, in contrast to administrative cost where the optimal scale increases over time. The optimal scale estimate of 
investment costs fluctuates heavily over time, pointing to lack of robustness. For investment costs it is important to consider the asset allocation as well since, particularly in recent years, large pension funds invest more in risky assets which go with higher risk management costs. Ignoring this size effect would affect the scale economy measurement: stocks and real estate do indeed carry significant higher costs than e.g. bonds.

Annual operational costs have a huge impact on future pension fund benefits, because they erode pension wealth year after year. This effect is stronger the lower the returns are. Reducting such costs as much as possible should be an important policy for every pension fund. Consolidation among smaller pension funds would greatly benefit their cost efficiency. We also observe huge cost difference within each size class, with potential great possibilities to reduce costs. So, particularly for administrative activities, we find significantly higher costs for company funds and professional group funds compared to industry funds (controlled for size, etc.), though decaying somewhat over time.

Other, more idiosyncratic causes of cost difference require further investigation.

\section{References}

Adanu, K., J. Hoehn, E. Iglesias, 2009, Cost function estimation in the water industry-functional forms and efficiency measures, essay 3, Department of Agricultural Economics, presented at the 2009 USDA-CSREES National Water Conference; St. Louis, MO (February), and at the First Annual Graduate Academic Conference Michigan State University, East Lansing (March).

Akaike, H., 1974, A new look at the statistical model identification, IEEE Transactions on Automatic Control 19, 716-723.

Ambachtsheer, K., 2010, Future directions in measuring the financial performance of pension funds: a roundtable discussion, in: R. Hinz, R. Heinz, P. Antolin, J. Yermo (eds.), Evaluating the Financial Performance of Pension Funds, Washington, DC: World Bank.

Andonov, A., R. Bauer, K.J.M. Cremers, 2011, Can large pension funds beat the market?

Decomposing the performance of pension funds into asset allocation, market timing and security selection components, http://icfpub.som.yale.edu/system/fileuploads/2699/original/2011_ICF_WPS_Can_Large_Pensi on_Funds_Beat_the_Markety_Cremers.pdf?1317766024 (Accessed December 31, 2012).

Bateman, H., S. Valdés-Prieto, 1999, The Mandatory Private Old Age Income Schemes of Australia and Chile: A Comparison, Mimeograph, University of New South Wales (Published as book in 2000, ISBN 13: 9780733416958 ).

Bateman, H., O.S. Mitchell, 2004, New evidence on pension plan design and administrative expenses: the Australian experience, Journal of Pension Economics and Finance 3, 63-76.

Bauer, R., K.J.M. Cremers, R.G.P. Frehen, 2010, Pension fund performance and costs: small is beautiful, Tilburg University, MPRA Paper No. 23556.

Bikker, J.A., L. Spierdijk, P.J. van der Sluis, 2007, Market impact costs of institutional equity trades, Journal of International Money and Finance 26, 974-1000.

Bikker, J.A., L. Spierdijk, R.P.M.M. Hoevenaars, P.J. van der Sluis, 2008, Forecasting market impact costs and identifying expensive trades, Journal of Forecasting 27, 21-39.

Bikker, J.A., J. de Dreu, 2009, Operating costs of pension funds: the impact of scale, governance, and plan design, Journal of Pension Economics and Finance 8, 63-89.

Bikker, J.A., L. Spierdijk, P.J. van der Sluis, 2010, What factors increase the risk of incurring high market impact costs?, Applied Economics 42, 369-387. 
Bikker, J.A., O.W. Steenbeek, F. Torracchi, 2012, The impact of scale, complexity, and service quality on the administrative costs of pension funds: A cross-country comparison, Journal of Risk and Insurance 79, 477-514.

Canback, S., P. Samouel, D. Price, 2006, Do diseconomies of scale impact firm size and performance?, Journal of Managerial Economics 4, 27-70.

Caswell, J.W., 1976, Economic efficiency in pension plan administration: A study of the construction Industry, Journal of Risk and Insurance 4, 257-273.

Chatterton, M., E. Smyth, K Darby, 2010, Pension scheme administrative costs, Department for Work and Pensions, Working Paper No 91, London.

Christensen, L.R., W.H. Greene, 1976, Economies of scale in US electric power generation, Journal of Political Economy 84, 655-676.

Collins, S., Ph. Mack, 1997, The optimal amount of assets under management in the mutual fund industry, Financial Analyst Journal 53, 67-73.

Dietsch, M., 1993, Economies of scale and scope in French commercial banking industry, The Journal of Productivity Analysis 4, 35-50.

Dobronogov, A., M. Murthi, 2005, Administrative fees and costs of mandatory private pensions in transition economies, Journal of Pension Economics and Finance 4, 31-55.

Dyck, A., L. Pomorski, 2011, Is bigger better? Size and performance in pension plan management, http://www.moneyscience.com/pg/bookmarks/Admin/read/98439/is-bigger-better-size-andperformance-in-pension-plan-management (Accessed: December 31, 2012)

Edirisuriya, P., G. O'Brien, 2001, Financial deregulation and economies of scale and scope: evidence from the major Australian banks, Asia-Pacific Financial Markets 8, 197-214.

Griffin, D., A. Tversky, 1992, The weighing of evidence and the determinants of confidence, Cognitive Psychology 24, 411-435.

Hernandez, D. G., F. Stewart, 2008, Comparison of Costs + Fees in Countries with Private Defined Contribution Pension System, Working Paper No. 6, International Organization of Pension Supervisions (IOPS), http://www.oecd.org/site/iops/41269747.pdf (accessed December 31, 2012).

Indro, D.C., C.X. Jiang, M.Y. Hu, W.Y. Lee, 1999, Mutual fund performance: Does fund size matter?, Financial Analysts Journal 55, 74-87.

Ippolito, R.A., 1989, Efficiency with costly information: A study of mutual fund performance, 19651984, Quarterly Journal of Economics 54, 1-23.

James, E., J. Smalhout, D. Vittas, 2001, Administrative costs and the organization of individual retirement account systems: A comparative perspective, in: R. Holzmann and J. Stiglitz (ed.), New Ideas About Old Age Security, Washington DC: World Bank; revised version published in Private Pensions Systems: Administrative Costs and Reforms, Paris: OECD.

Jensen, M.C., 1968, The performance of mutual funds in the period 1945-1964, The Journal of Finance 23, 389-416.

Koeleman, W.J.J., J.J.B. de Swart, 2007, Kosten en baten van ondernemingspensioenfondsen (In Dutch; Cost and benefits of company pension funds), PWC, Amsterdam.

Konings, J., F. Roodhooft, 2002, The effect of E-business on corporate performance: firm level evidence for Belgium, De Economist 150, 569-581.

Lakonishok, J., A. Schleifer, R.W. Vishny, 1992, The structure and performance of the money management industry, Brookings Papers on on Economic Activity: Microeconomics, 339- 391.

McKenna, F.W., Y.H. Kim, 1986, Managerial risk preferences, real pension costs, and long-run corporate pension fund investment policy, The Journal of Risk and Insurance 53, 29-48.

Malhotra, D.K., R.W. Mcleod, 1997, An empirical analysis of mutual fund expenses, The Journal of Financial Research 20, 175-190.

Malhotra, D. K., V. B. Marisetty, M. Ariff, 2001, Economies of Scale in Retail Superannuation Funds in Australia, Working Paper, Monash University.

Malkiel, B.G., 1995, Returns from investing in equity mutual funds 1971 to 1991, The Journal of Finance 50, 549-572.

Mitchell, O.S., 1998, Administrative Costs in Public and Private Retirement Systems, University of Chicago Press. 
Mitchell, O.S., E.S. Andrews, 1981, Scale Economies in Private Multi-Employer Pension Systems, Industrial and Labor Relations Review 34, 522-530.

Nauriyal, B.B., 1995, Measures of cost economies in Chilean banking: 1984-1991, Revista de analisis economico 10, 71-99.

Shaffer, S., 1998, Functional forms and declining average costs, Journal of Financial Services Research 14, 91-115.

Swank, J. 1996, How stable is the multiproduct translog cost function? Evidence from the Dutch banking industry, Kredit und Kapital 29, 153-172.

Sy, W., 2007, Cost, Performance and Portfolio Composition of Small APRA Funds, Working Paper, Australian Prudential Regulation Authority, Sydney.

Tapia, W., J. Yermo, 2008, Fees in Individual Account Pension Systems: A Cross- Country Comparison, OECD Working Papers on Insurance and Private Pensions No. 27.

White, H., 1980, Using least squares to approximate unknown regression functions, International Economic Review 21, 149-170.

Whitehouse, E., 2000, Administrative Charges for Funded Pensions: An International Comparison and Assessment, Pension Reform Primer Series, Social Protection Discussion Paper No. 16, The World Bank, Washington DC.

\section{Appendix: Weighted regression of the administrative cost model}

Table A.1 presents the estimates of the weighted regressions of the TCM and the SULF. Compared to unweighted (Table 6.2), the average cost elasticities for the two models have increased somewhat, but remain highly significantly different from 1 , implying the existence of highly significant scale economies. The coefficient of the squared term is now stable over time in the TCF at 0.02 and highly significantly (and quite stable in the ULF), while it fell from 0.04 to 0 over time in the unweighted regression. A final difference is that, starting in 1993, the coefficient of the SULF reciprocal term is highly significant now. All these changes indicate that the functional form of the cost elasticity is slightly different now that observations of larger pension funds have higher weights in the regression, though without significant changes in the conclusions. As a result the estimated optimal scale is somewhat higher in the earlier period (1992-1999) and lower in later years. Fig. 6.2 shows that the $95 \%$ confidence band of the optimal scale is large, so that the optimal scale value is quite uncertain. Of course, this is due to the fact that the optimal scale lies in the tail of the size distribution. 
Table A.1. Optimal scale of pension funds' administration by year (weighted regression)

\begin{tabular}{|c|c|c|c|c|c|c|c|c|c|c|c|c|}
\hline \multirow[b]{2}{*}{ Year } & \multicolumn{5}{|c|}{ Translog cost model } & \multicolumn{7}{|c|}{ Simplified ULM } \\
\hline & $\begin{array}{l}\text { \# } \\
\text { Ob- } \\
\text { ser- } \\
\text { vat- } \\
\text { ions }\end{array}$ & $\begin{array}{l}\text { Cost } \\
\text { elas- } \\
\text { ticity }\end{array}$ & $\begin{array}{r}\text { Coeff } \\
\text { square } \\
\text { term }\end{array}$ & $\begin{array}{r}\text { Opti- } \\
\text { mal } \\
\text { size }(x \\
1000)\end{array}$ & $\begin{array}{r}\text { Log- } \\
\text { like- } \\
\text { lihood }\end{array}$ & $\begin{array}{r}\text { Cost } \\
\text { elast- } \\
\text { icity }\end{array}$ & $\begin{array}{r}\text { Coeff. } \\
\text { ln- } \\
\text { partici- } \\
\text { pants }\end{array}$ & $\begin{array}{r}\text { Coeff } \\
o \\
\text { squarec } \\
\text { term }\end{array}$ & & $\begin{array}{r}\text { Coeff. of } \\
\text { reci- } \\
\text { procal }^{\text {term }}{ }^{a}\end{array}$ & $\begin{array}{r}\text { Opti- } \\
\text { mal } \\
\text { size }(x \\
1000)\end{array}$ & $\begin{array}{r}\text { Log } \\
\text { likeli- } \\
\text { hood }\end{array}$ \\
\hline 1992 & 759 & 0.76 & 0.02 & 65 & -1128 & 0.76 & 0.75 & 0.03 & & -0.24 & 64 & $-1,128$ \\
\hline 1993 & 792 & 0.76 & 0.02 & 112 & -1147 & 0.76 & 0.73 & 0.02 & 3 & -0.91 & 104 & $-1,147$ \\
\hline 1994 & 788 & 0.77 & 0.02 & 65 & -1131 & 0.76 & 0.73 & 0.03 & 3 & -1.31 & 85 & $-1,131$ \\
\hline 1995 & 789 & 0.80 & 0.02 & 65 & -1111 & 0.79 & 0.76 & 0.02 & 3 & -1.20 & 62 & $-1,110$ \\
\hline 1996 & 786 & 0.81 & 0.02 & 41 & -1083 & 0.80 & 0.75 & 0.03 & 3 & -2.19 & 43 & $-1,082$ \\
\hline 1997 & 776 & 0.87 & 0.01 & 71 & -1015 & 0.85 & 0.80 & 0.02 & 3 & -2.24 & 69 & $-1,014$ \\
\hline 1998 & 784 & 0.81 & 0.02 & 55 & -1063 & 0.79 & 0.71 & 0.03 & 3 & -3.59 & 57 & $-1,061$ \\
\hline 1999 & 754 & 0.81 & 0.02 & 189 & -952 & 0.79 & 0.74 & 0.02 & 3 & -2.62 & 155 & -951 \\
\hline 2000 & 768 & 0.76 & 0.02 & 401 & -936 & 0.74 & 0.67 & 0.03 & 3 & -3.19 & 284 & -934 \\
\hline 2001 & 756 & 0.66 & 0.03 & 531 & -1017 & 0.63 & 0.49 & 0.04 & 3 & -6.57 & 325 & $-1,012$ \\
\hline 2002 & 719 & 0.70 & 0.02 & 1,770 & -881 & 0.68 & 0.59 & 0.03 & 3 & -4.42 & 859 & -879 \\
\hline 2003 & 694 & 0.70 & 0.02 & 1,168 & -784 & 0.68 & 0.62 & 0.03 & 3 & -3.53 & 777 & -782 \\
\hline 2004 & 647 & 0.69 & 0.02 & 41,371 & -704 & 0.68 & 0.63 & 0.02 & 3 & -3.07 & 11,893 & -703 \\
\hline 2005 & 643 & 0.71 & 0.02 & 8,748 & -733 & 0.69 & 0.59 & 0.03 & 3 & -5.77 & 2,409 & -731 \\
\hline 2006 & 590 & 0.70 & 0.01 & 256,673 & -644 & 0.69 & 0.63 & 0.02 & 3 & -3.03 & 14,455 & -643 \\
\hline 2007 & 542 & 0.62 & 0.02 & 15,674 & -520 & 0.60 & 0.48 & 0.03 & 3 & $-7.43^{3}$ & 3,905 & -518 \\
\hline 2008 & 490 & 0.63 & 0.02 & 41,703 & -452 & 0.62 & 0.56 & 0.02 & 3 & $-3.94^{3}$ & 13,376 & -451 \\
\hline 2009 & 444 & 0.65 & 0.02 & 31,653 & -409 & 0.64 & 0.60 & 0.02 & 3 & -2.59 & 14,815 & -409 \\
\hline$\overline{A v g s}$ & & 0.77 & & & & 0.75 & & & & & & \\
\hline Sum & 12,521 & & & & $-15,710$ & & & & & & & $-15,685$ \\
\hline
\end{tabular}

${ }^{\text {a }}$ Super indices 1,2 and 3 indicate significance levels of, respectively, $10 \%, 5 \%$ and $1 \%$. 